\title{
A Comprehensive Review of the Major Genes Conditioning Resistance to Anthracnose in Common Bean
}

\author{
James D. Kelly and Veronica A. Vallejo \\ Crop and Soil Sciences, Michigan State University, East Lansing MI 48824
}

Additional index words. alleles, Colletotrichum lindemuthianum, co-localization, differential cultivars, gene clusters, genetic linkage maps, gene pyramiding, molecular markers, pathogen races, Phaseolus vulgaris, quantitative trait loci, QTL, resistant gene loci

\begin{abstract}
Resistance to anthracnose in common bean is conditioned primarily by nine major independent genes, $\mathrm{Co}-1$ to $\mathrm{Co}-10$ as the $\mathrm{Co}-3 / \mathrm{Co}-9$ genes are allelic. With the exception of the recessive $c o-8$ gene, all other nine are dominant genes and multiple alleles exist at the $\mathrm{Co}-\mathrm{I}, \mathrm{Co}-3$ and $\mathrm{Co}-4 \mathrm{loci}$. A reverse of dominance at the $\mathrm{Co}-1$ locus suggests that an order of dominance exists among individual alleles at this locus. The nine resistance genes $\mathrm{Co}-2$ to Co-10 are Middle American in origin and $\mathrm{Co}-1$ is the only locus from the Andean gene pool. Seven resistance loci have been mapped to the integrated bean linkage map and $\mathrm{Co}-1$ resides on linkage group B1; Co-2 on B11, $\mathrm{Co}-3$ on B4; Co-4 on B8; Co-6 on B7; and $\mathrm{Co}-9$ and $\mathrm{Co}$ 10 are located on $\mathrm{B} 4$ but do not appear to be linked. Three $C o$-genes map to linkage groups B1, B4 and B11 where clusters with genes for rust resistance are located. In addition, there is co-localization with major resistance genes and QTL that condition partial resistance to anthracnose. Other QTL for resistance may provide putative map locations for the major resistance loci still to be mapped. Molecular markers linked to the majority of major $\mathrm{Co}$ genes have been reported and these provide the opportunity to enhance disease resistance through marker-assisted selection and gene pyramiding. The $10 \mathrm{Co}$-genes are represented in the anthracnose differential cultivars, but are present as part of a multi-allelic series or in combination with other $\mathrm{Co}$-genes, making the characterization of more complex races difficult. Although the $\mathrm{Co}$-genes behave as major Mendelian factors, they most likely exist as resistance gene clusters as has been demonstrated on the molecular level at the $\mathrm{Co}-2$ locus. Since the genes differ in their effectiveness in controlling the highly variable races of the anthracnose pathogen, the authors discuss the value of individual genes and alleles in resistance breeding and suggest the most effective gene pyramids to ensure long-term durable resistance to anthracnose in common bean.
\end{abstract}

One of the longest studied plant-pathogen interactions is that between common bean, Phaseolus vulgaris L., and Colletotrichum lindemuthianum (Sacc. \& Magnus) Briosi \& Cav., the causal organism of bean anthracnose. In studies with bean anthracnose, Barrus (1911) was the first to demonstrate the existence of physiological races of plant pathogens, whereas, Burkholder(1918) provided the first information on the inheritance of disease resistance in plants. Using race specific elicitors of $C$. lindemuthianum, scientists studied the signal transduction mechanisms of plant defense in common bean and cloned many of the genes functional in the phenylpropanoid pathway (Lamb et al., 1989). The interaction between the pathogenic diversity of $C$. lindemuthianum and the gene pool diversity of the host has been studied (Balardin and Kelly, 1998; Sicard et al., 1997), and ancestral

Received for publication 22 Apr. 2003. Accepted for publication 9Dec. 2003. The authors wish to recognize the foresight of M.A. 'Talo' Pastor-Corrales in establishing the 12-member anthracnose differential series without which this work would not have been possible; and to Maeli Melotto for her critical review and constructive comments during the preparation of this manuscript. Support from the USAID Bean/Cowpea Collaborative Research Support Program grant DAN 1310-G-SS-6008-00 and the Michigan Agricultural Experiment Station is recognized. resistance gene clusters involved in co-evolution of host and pathogen have been identified (Geffroy et al., 1999). More recently, anthracnose resistance genes have been used to integrate physical and genetic linkage maps of common bean (Melotto et al., 2004) and have also been the major focus of map-based cloning efforts in common bean and resistance gene analogues (RGA) have beenidentified (Creusotetal., 1999; Ferrier-Cana et al., 2003; Geffroy et al., 1998; López et al., 2003; Melotto and Kelly, 2001, Melotto et al., 2004).

Anthracnose is regarded as the most serious disease of common bean worldwide due, in large part, to its seed-borne nature and pathogenic variability. Transmission of the pathogen through the seed is very efficient (Dillard and Cobb, 1993; $\mathrm{Tu}, 1992$ ), which is problematic not only for subsistence farmers in LatinAmerica and Africa, but also for commercial farmers in North America looking for ways to reduce production costs by saving their own seed. C. lindemuthianum is a highly variable pathogen (Balardin et al., 1997; Pastor-Corrales et al., 1995; RodriguezGuerra et al., 2003), and resistance in the host is assumed to follow the gene-for-gene theory (Flor, 1947); however, pathogen information is limited due to the inability to carry out genetic studies on the pathogen. With the exception of recent reports on partial resistance, where co-localization between quantitative trait loci (QTL) controlling the partial resistance and 'defeated' major genes inferred that partial resistance may be the residual effect of defeated major genes (Geffroy et al., 2000; López et al., 2003), single major genes in common bean provide resistance to multiple races of the anthracnose pathogen (Mastenbroek, 1960). Ten major genes identified with the Co symbol (Alzate-Marin et al., 2002b; Geffroy et al., 1999; Kelly and Young, 1996; Melotto et al., 2000a), are described in the literature. In most instances, independency of the $\mathrm{Co}$-genes is clearly demonstrated. Provisional symbols proposed for other loci (Geffroy, 1997; Geffroy et al., 1999) will be discussed in relation to the ten independent loci conditioning resistance to anthracnose. A number of anthracnose resistance genes with letter symbols appear in the historical literature but have been replaced with the Co symbol followed by a numerical designation (Kelly and Young, 1996). International standardization of C. lindemuthianum races is based on disease reaction of 12 differential host cultivars, each assigned a binary code from 1 to 2048 (Table 1; Pastor-Corrales, 1991). Virulent races are assigned a number representing the summation of the binary numbers of the susceptible differential cultivars. The traditional Greek symbols used previously for race identification have been superseded by the binary codes and the two race identification systems are listed for purposes of comparison (Melotto et al., 2000a).

Genetic resistance is recognized as the most effective disease management strategy for the control of bean anthracnose. Despite the extensive literature on resistance to this disease, bean breeders still struggle with the decision as to which gene(s) to deploy in resistance breeding programs. Given the recent activity in mapping and gene tagging, new information on the location of most major genes controlling resistance to anthracnose is now available (Kelly et al., 2003). Information on the resistance spectra of different resistance genes to a wide array of pathogenic races (Balardin et al., 1997), the independence of resistance genes or lack thereof, based on complementation tests, and the location on the integrated BAT $93 \times$ Jalo EEP558 (BJ) bean map (Freyre et al., 1998) in relation to other anthracnose resistance genes and QTL is summarized to assist breeders in the choice of resistance genes or alleles for breeding (Fig. 1). In addition, markers linked to different resistance loci are presented to provide additional information on independence and afford the opportunity for the use of marker-assisted selection (MAS) in developing valuable gene pyramids with genes of complementary gene action from the two major gene pools of common bean (Gepts, 1988; Kelly and Miklas, 1998; Kelly etal., 2003). This review is organized in sections by the ten major anthracnose resistance loci in common bean, and information available for the gene(s) at each major locus is presented in a format that should be useful for bean breeders, pathologists, and geneticists alike.

\section{Locus Co-1}

Origin: The $\mathrm{Co}-1$ gene, originally known as the $A$ gene, was first described in 'Well's Red Kidney' (Barrus, 1915). Actually, Co- 1 was the 

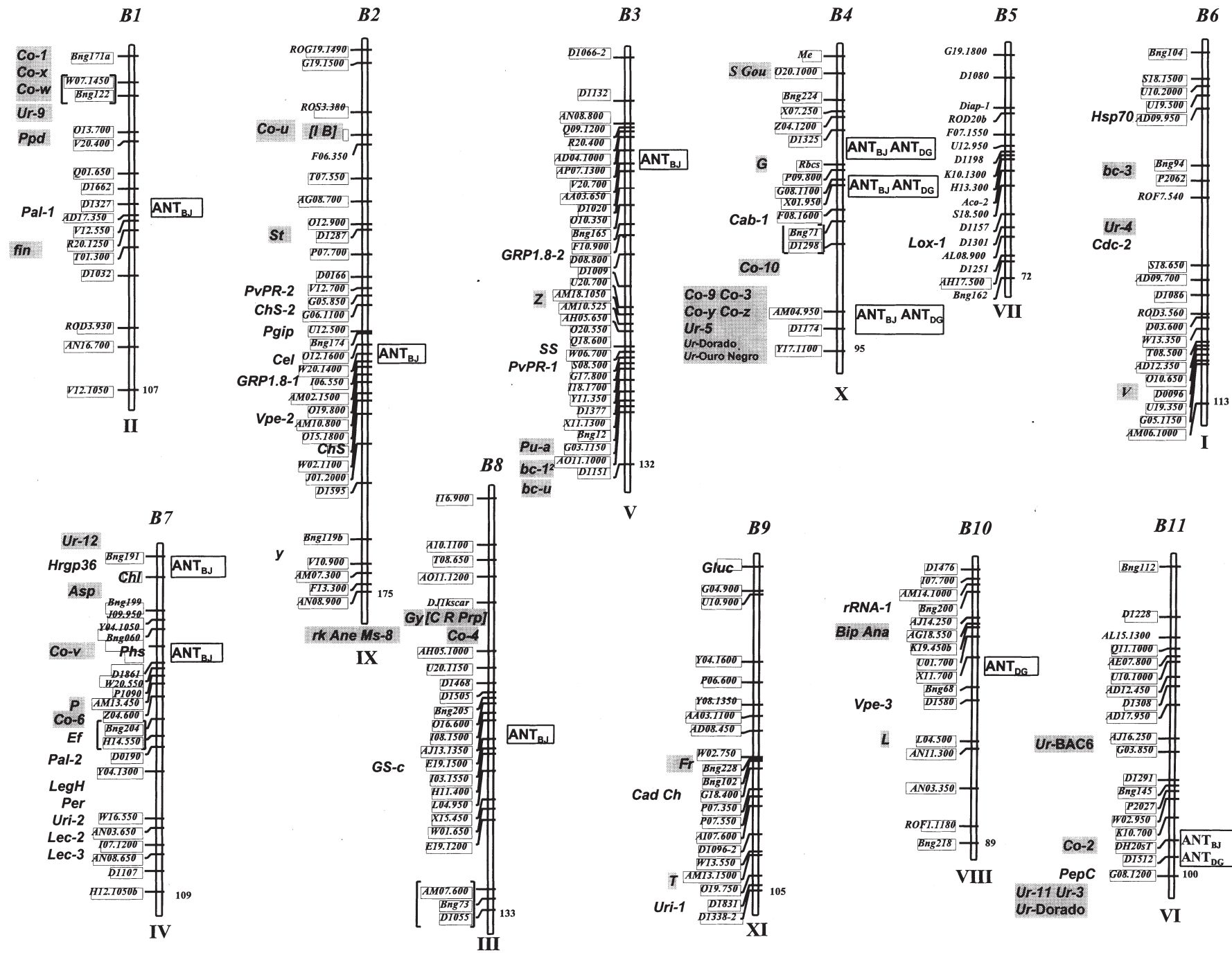

Fig. 1. Common bean linkage map (B1-B11; Freyre et al., 1998) and bean chromosomal map (I-XI; Pedrosa et al., 2003). Genomic distribution of genes with a biochemical function (mostly disease response genes), major genes coding for phenotypic traits, and QTL in common bean. Each linkage group is represented by the core map version (Freyre et al., 1998) and updated maps (Gepts, 1999; Kelly et al., 2003; Pedrosa et al., 2003). The current map is based on the map of Kelly et al. (2003) with the addition of QTL conditioning resistance to anthracnose in the two mapping populations BAT 93/Jalo EEP558 (BJ; Geffroy et al., 2000) and DOR364/G19833 (DG; López et al., 2003). To the left of each linkage group, are the framework molecular markers (smaller font) and the biochemical genes (larger font) and major phenotypic trait genes (shaded boxes). The Co loci are anthracnose resistance loci (Geffroy 1997; Geffroy et al., 1999; 2000; Kelly and Young, 1996; Melotto et al., 2000a; Rodríguez-Suárez et al., 2004; Vallejo and Kelly, 2002; Young et al., 1998). The Ur loci are rust resistance loci including the Pu-a for abaxial leaf pubescence (Kelly et al., 1996, 2003; Steadman et al., 2002). The $I$ gene is a dominant resistance and $b c-u, b c-l^{2}$ and $b c-3$ are recessive genes for resistance to bean common mosaic virus (Drijfhout, 1978; Miklas et al., 2000b). Fin, Ppd, St are genes for determinacy, sensitivity to photoperiod, and pod string formation (Gepts, 1999). B, [C R Prp], G, P, and rk are seed color genes and Ana, Ane, Bip, L, T and Z are seed color pattern genes (Bassett, 1996; McClean et al., 2002). Asp is a gene for seedcoat shininess (Gepts, 1999). To the right (boxed symbols), are QTL for anthracnose (ANT) mapped in different populations (BJ, Geffroy et al., 2000; DG, López et al., 2003). Location of most genes is approximate, as most were not directly mapped in the BAT93/Jalo EEP558 population. The total distance of each linkage group (expressed in Kosambi cM) is shown at the right of the location of the bottom marker of that linkage group.

first disease resistance gene described in common bean and the first genotype by pathogen race interaction was demonstrated with this particular gene and isolates of anthracnose (Barrus, 1911, 1915, 1918; Burkholder, 1918, 1923; McRostie, 1919). The Co- 1 allele is present in 'Michigan Dark Red Kidney' (MDRK), which carries the binary number 2 in the anthracnose differential series (Table 1; Melotto et al. 2000a). Among all loci characterized as conditioning resistance to anthracnose, $\mathrm{Co}-1$ is the only locus originating in the Andean gene pool of common bean (Gepts, 1988). OtherAndean resistance sources, such as A193, previously considered to be independent genes have since been shown to possess the $\mathrm{Co}-1$ gene (Mendoza et al., 2001). The popular Andean cultivar Diacol Calima displayed the same resistance spectra as MDRK to inoculation with $30+$ isolates of anthracnose from Europe and Colombia (Schwartz et al., 1982), suggesting that it also possesses similar resistance gene(s). The Andean genotype Jalo EEP558, used as a parent to construct the bean integrated linkage map (Freyre et al., 1998), has been shown to carry one major gene at the Co-1 locus. In a cross of Jalo EEP558 with 'Perry Marrow', the $F_{2}$ population segregated in a 3:1 ratio $(p=0.34)$ of resistant to susceptible individuals when inoculated with race 357 (Vallejo, unpublished data). Allelism tests conducted with an $\mathrm{F}_{2}$ population from the $\mathrm{RxR}$ cross Jalo EEP558 with MDRK inoculated with race 73 indicated that Jalo EEP558 carries an allele at the Co- 1 locus (Vallejo et al., 2003). Ten races of $C$. lindemuthianum differentiated Jalo EEP558 from all reported alleles except the allele carried by MDRK ( $\mathrm{Co}-1)$, suggesting that it also possesses the same allele at the Co-1 locus as MDRK (Vallejo et al., 2003). Other highly resistant Andean sources, such as 'PC 50', have a similar resistance pattern to the cultivar Kaboon (Balardin and Kelly, 1998), but the presence of $\mathrm{Co}-1$ locus in 'PC 50' has yet to be confirmed in inheritance studies.

Alleles: Three Andean cultivars, MDRK, Perry Marrow, and Kaboon in the differential series carry different alleles at the $C o$ - 1 locus (Table 2). In addition to the $\mathrm{Co}-1$ allele in MDRK, two other alleles $\mathrm{Co}-\mathrm{I}^{2}$ and $\mathrm{Co}-\mathrm{I}^{3}$ present in the differential cultivars Kaboon (Race Nueva Granada), Perry Marrow (Race Chile; Pastor-Corrales et al., 1995), respectively, have been reported at the $\mathrm{Co}-1$ locus (Melotto and Kelly, 2000). A fourth allele $\mathrm{Co}^{-1}{ }^{4}$ was 
Table 1. Anthracnose differential series, resistance genes, host gene pool, and the binary number of each differential cultivar, used in the characterization of races of Colletotrichum lindemuthianum in common bean.

\begin{tabular}{|c|c|c|c|}
\hline $\begin{array}{l}\text { Differential } \\
\text { cultivar }\end{array}$ & $\begin{array}{l}\text { Host } \\
\text { gene }^{z}\end{array}$ & $\begin{array}{l}\text { Gene } \\
\text { pool }^{\mathrm{y}}\end{array}$ & $\begin{array}{c}\text { Binary } \\
\text { no. }^{x}\end{array}$ \\
\hline Michelite & --- & MA & 1 \\
\hline Michigan Dark Red Kidney & Co-1 & A & 2 \\
\hline Perry Marrow & $\mathrm{Co}-1^{3}$ & A & 4 \\
\hline Cornell 49242 & Co- 2 & MA & 8 \\
\hline Widusa & --- & MA & 16 \\
\hline Kaboon & $\mathrm{Co}-1^{2}$ & A & 32 \\
\hline Mexico 222 & Co-3 & MA & 64 \\
\hline PI 207262 & $\mathrm{Co}-4^{3}, \mathrm{Co}-9$ & MA & 128 \\
\hline TO & $\mathrm{Co}-4$ & MA & 256 \\
\hline TU & Co- 5 & MA & 512 \\
\hline AB 136 & Co- 6, co- 8 & MA & 1024 \\
\hline G 2333 & $\mathrm{Co}-4^{2}, \mathrm{Co}-5, \mathrm{Co}-7$ & MA & 2048 \\
\hline
\end{tabular}

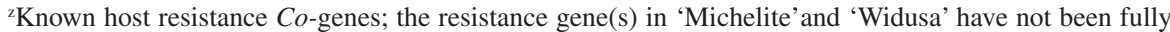
characterized.

${ }^{\mathrm{y}} \mathrm{MA}=$ Middle American gene pool; $\mathrm{A}=$ Andean gene pool of the host (Gepts, 1988).

${ }^{x}$ Binary number: for $2^{n}, n$ is equivalent to the place of the differential cultivar within the series. The sum of cultivars with susceptible reaction will give the binary number of a specific race (Melotto et al., 2000a; Pastor-Corrales, 1991); e.g., race 17 = virulent on 'Michelite' (1) + 'Widusa' (16). Where other race designations were used, the authors have attempted to provide the race number using the binary code when possible.

recently reported in the Calima-type Andean cultivar AND 277 (Alzate-Marin et al., 2003a), whereas the actual alleles at the $\mathrm{Co}-1$ locus in the Andean cultivar Montcalm, and the Middle American(MA) cultivars, Tuscola, Seafarer and Raven have not been fully identified (Muhalet et al., 1981; Young and Kelly, 1996c, 1997b). A fifth tentative allele $\mathrm{Co}-\mathrm{I}^{5}$ in the MA cultivar Widusa has been proposed (Gonçalves-Vidigal et al., 2003). The confusion in the published data on 'Widusa' prevents the authors from confirming the existence of a fifth allele at the Co- 1 locus at this time. The locus is complex and other alleles yet to be described probably exist within Andean germplasm. Recognizing that dominant genes primarily condition resistance to anthracnose, recessive resistance has been documented at the $\mathrm{Co}-1$ locus (Andrus and Wade, 1942; Cardenas et al., 1964; Muhalet et al., 1981). The occurrence of recessive resistance pattern in a genotype previously identified as being controlled by dominant resistance genes results from the presence of a multi-allelic series at the resistance locus where a prior order of dominance has been established between alleles at the locus (Melotto and Kelly, 2000; Miklas et al., 2000b). The reversal of dominance observed in segregating populations inoculated with race 130 (beta; Cardenas et al., 1964; Muhalet et al., 1981) can be explained as a multi-allelic series residing at the $\mathrm{Co}-1$ locus with differing degrees of dominance existing between the alleles. Reversal of dominance is observed in the same resistant cultivar due the dominance relationships that exist between the alleles segregating in the population, after inoculation with different races of the pathogen. As a result, recessive resistance is reported since the recessive allele confers resistance to the particular race of the pathogen to which the dominant allele is susceptible. In complementation crosses, the question of allelism versus linkage at a locus will always exist with small segregating populations ( $<200$ individuals). The authors have chosen to evoke a traditional interpretation of an allelic series at a locus similar to the 10 alleles described at the $P m 3$ locus in wheat (Triticum aestivum; Zeller and Hsam, 1998) as an explanation for the lack of segregation in complementation $(\mathrm{R} \times \mathrm{R})$ crosses rather than the existence of a tight linkage with other unknown genes at or near the locus in question. Since a multi-allelic series exists at the $\mathrm{Co}-1$ locus, a similar explanation of allelism for the lack of segregation in complementation crosses at other resistance loci is most plausible.

Markers: Despite the uniqueness of the Co- 1 locus as the only anthracnose resistance source in the Andean gene pool, markers linked to this locus have been difficult to find (Melotto et al., 2000b). Two repulsion phase markers have been reported (RAPD, Young and Kelly, 1997a; AFLP, Mendoza et al., 2001) and one co-dominant STS marker, $\mathrm{SE}_{\mathrm{ACT}} / \mathrm{M}_{\mathrm{CCA}}$, has been identified linked to the $\mathrm{Co}-1$ locus (Table 2; Vallejo and Kelly, 2002).

Map location: The Andean Co-1 locus was mapped to linkage group B1 using $\mathrm{SE}_{\mathrm{ACT}} / \mathrm{M}_{\mathrm{CCA}}$ marker in the $\mathrm{BJ}$ recombinant inbred line (RIL) mapping population (Fig. 1; Vallejo and Kelly, unpublished data). Data confirming the location of $\mathrm{Co}-1$ on B1 comes from Mendez de Vigo (2001) who used the repulsion marker (Young and Kelly, 1997a) to map Co-1. Indirectevidence comes from the positioning of two provisionally assigned loci $C o-x$ and $C o-w$ (Geffroy, 1997) to B1 (Gepts, 1999). Both loci come from Jalo EEP558 parent in the BJ mapping population. The $C o$ - 1 locus appears to be located near the fin (determinate growth habit) and $P p d$ (photoperiod sensitivity) genes on $\mathrm{B} 1$. The fin gene occurs at high frequency in the cultivated Andean gene pool compared with the MA gene pool (Singh et

Table 2. New and original gene symbols, genetic sources, gene pools, linked markers and map location for major genes conditioning resistance to anthracnose in common bean.

\begin{tabular}{|c|c|c|c|c|c|c|}
\hline \multicolumn{2}{|c|}{ Gene symbol } & \multirow{2}{*}{$\begin{array}{l}\text { Genetic } \\
\text { source }\end{array}$} & \multirow{2}{*}{$\begin{array}{l}\text { Gene } \\
\text { pool }\end{array}$} & \multirow{2}{*}{$\begin{array}{l}\text { Linked } \\
\text { marker }\end{array}$} & \multirow{2}{*}{$\begin{array}{l}\text { Map } \\
\text { location }\end{array}$} & \multirow[b]{2}{*}{ References } \\
\hline New & Original & & & & & \\
\hline$\overline{\mathrm{Co}-1}$ & $A$ & MDRK & Andean & OF10 & B1 & McRostie, 1919; Vallejo and Kelly, 2002 \\
\hline $\mathrm{Co}-\mathrm{I}^{2}$ & & Kaboon & & $\mathrm{SE}_{\mathrm{ACT}} / \mathrm{M}_{\mathrm{CCA}}$ & & \\
\hline $\mathrm{Co}-1^{3}$ & & Perry Marrow & & & & Melotto and Kelly, 2000 \\
\hline $\mathrm{Co}-1^{4}$ & & AND 277 & & & & Alzate-Marin et al., 2003a \\
\hline Co-2 & Are & Cornell 49242 & MA & $\mathrm{OQ}_{1440}$ & B11 & Mastenbroek, 1960 \\
\hline & & & & $\mathrm{OH} 2 \mathrm{O}_{450}$ & & Adam-Blondon et al., 1994a \\
\hline & & & & B355 1000 & & Young and Kelly, 1996b \\
\hline $\mathrm{Co}-3$ & Mexique 1 & Mexico 222 & MA & NA & NA & Bannerot, 1965; Fouilloux, 1979 \\
\hline $\mathrm{Co}-3^{2}$ & & Mexico 227 & & & & \\
\hline Co-4 & Mexique 2 & TO & MA & SAS13, SH18 & B8 & $\begin{array}{l}\text { Awale and Kelly, 2001; Fouilloux, 1979, Young et al., 1998; } \\
\text { de Arruda et al., } 2000\end{array}$ \\
\hline $\mathrm{Co}-4^{2}$ & & SEL1308 & & SBB14, OC8 & & \\
\hline $\mathrm{Co}-4^{3}$ & & PI 207262y & & OY20 & & \\
\hline Co-5 & Mexique 3 & $\mathrm{TU}$ & MA & $\mathrm{OAB}_{450}$ & NA & Young et al., 1998; Vallejo and Kelly, 2001; Young and Kelly, \\
\hline & & SEL1360 & & SAB3 & & \\
\hline Co-6 & Q & AB 136 & MA & $\begin{array}{l}\text { OAH1 } \\
\text { OAK20 } \\
{ }_{890}\end{array}$ & B7 & Gonçalves-Vidigal, 1994; Young and Kelly, 1996a, 1997a \\
\hline Co-7 & $\mathrm{NA}^{\mathrm{z}}$ & $\begin{array}{l}\text { MSU-7 } \\
\text { G } 2333^{y}\end{array}$ & MA & NA $\quad 890$ & NA & Young et al., 1998 \\
\hline $\mathrm{co}-8$ & NA & AB 136 & MA & OPAZ20 & NA & Alzate-Marin et al., 2001b \\
\hline Co-9 & NA & BAT 93 & MA & SB12 & B4 & Geffroy et al., 1999 \\
\hline Co-10 & NA & Ouro Negro & MA & F10 & B4 & Alzate-Marin et al., 2003b \\
\hline
\end{tabular}

${ }^{\mathrm{z}} \mathrm{NA}=$ none available; $\mathrm{MDRK}=$ Michigan Dark Red Kidney; MA = Middle American.

yPI 207262 possesses 2-genes; G 2333 possesses 3-genes. 
al., 1991). Other resistance genes located in the vicinity of the $C o-1$ is the Andean $U r-9$ gene in 'PC 50' that conditions resistance to bean rust (causal organism Uromyces appendiculatus; Kelly et al., 2003).

Breeding value: The Co- 1 locus is present in the majority of Andean beans surveyed, with allelic differences existing between cultivars. This locus, however, is very valuable in the breeding of beans of MA origin, particularly in those countries where MA races of the anthracnose fungus predominate (Balardin et al., 1997; Balardin and Kelly, 1998). The Co- 1 locus is unique in importance to breeders developing gene pyramids with complementary genes from both $P$. vulgaris gene pools. Among the four confirmed alleles described at the $\mathrm{Co}-1$ locus, the $\mathrm{Co}-\mathrm{I}^{2}$ allele offers the broadest-based resistance but it appears to have been used the least by bean breeders. The $\mathrm{Co}-1$ allele appears to be widespreadinAndean germplasm resulting in a high level of susceptibility to Andean races in countries such as the Dominican Republic, Peru (Balardin and Kelly, 1998; Pastor-Corrales et al., 1995) and in northern Spain where Andean germplasm is grown widely (Ferreira et al., 1998). Breeders in these countries should exercise caution in choosing resistance alleles at the $C o-1$ locus, despite allelic differences in reaction to local races. Due to its effectiveness against the MA race 73 of $C$. lindemuthianum prevalent in North America, the $\mathrm{Co}-1$ gene has been successfully introgressed into MA black bean cultivars such as Jaguar, Phantom and Raven, and navy bean cultivars, Newport and Seafarer (Beaver et al., 2003).

\section{Locus Co-2}

Origin: The Co-2 gene originally known as the Are gene, was first described by Mastenbroek (1960) in the black bean genotype Cornell 49242 from Venezuela (Tables 1 and 2). The $\mathrm{Co}$-2 gene conditions resistance to four races (alpha17, beta-130, gamma-102 and delta-23) of $C$. lindemuthianum and was widely deployed as a resistance gene in both dry and snap bean breeding programs on all continents (Fouilloux, 1979; Leakey and Simbwa-Bunnya, 1972; Tu, 1992). Initially, the Co-2 was considered a 'horizontal' type resistance because it provides resistance to many races of the pathogen (Tu, 1992), but race specificity of the $\mathrm{Co}-2$ was detected as new virulent races rapidly emerged (Hubbeling, 1976, 1977). The extensive deployment of the $\mathrm{Co}-2$ gene resulted in the failure of this gene to provide resistance in North America (Kelly et al., 1994; Tu, 1994), South America (Balardin et al., 1997; Menezes and Dianese, 1988; PastorCorrales et al., 1995), Europe (Fouilloux, 1976, 1979; Hallard and Trebuchet, 1976; Hubbeling, 1976, 1977; Kruger et al., 1977), and Africa (Leakey and Simbwa-Bunnya, 1972).

Alleles: No alleles have been reported at the Co-2 locus. In the $\mathrm{R} x \mathrm{R}$ cross of bean cultivars Cornell 49-242 x Tuscola inoculated with race 102 (gamma), no susceptible individuals were observed among $214 \mathrm{~F}_{2}$ individuals, suggesting the presence of a second tightly linked resistance gene or another allele at the $\mathrm{Co}$-2 locus in 'Tuscola' (Muhalet et al., 1981). In contrast, a two gene (15:1) ratio observed in the same $\mathrm{R} \times \mathrm{R}$ cross inoculated with race 130 (beta) supports the theory of two independent genes. The confusion in the published data on 'Tuscola' prevents the authors from confirming the existence of a second allele at the $\mathrm{Co}-2$ locus at this time.

Markers: The Co-2 locus was the first anthracnose resistance locus to be tagged with RAPD and SCAR markers (Adam-Blondon et al., 1994a). A second pair of flanking markers was identified later (Young and Kelly, 1996b). All markers were linked in coupling. The $\mathrm{Co}-2$ locus has been the major focus of a map-based cloning effort, and candidate RGA exhibiting leucine rich repeats (LRR) and kinase proteins domains have been reported at this locus (Creusot et al., 1999; Ferrier-Cana et al., 2003; Geffroy et al., 1998).

Map location: The Co-2 locus was mapped to linkage group B11 (Adam-Blondon et al., 1994b) on the integrated BJ bean linkage map (Fig. 1; Freyre et al., 1998). The Co-2 allele has been confirmed to be present on B11 in other published maps (Gepts, 1999; Mendez de Vigo, 2001; Miklas et al., 2000a). Two linked regions that confer resistance to anthracnose were identified on $\mathrm{B} 11$, one of which was the $\mathrm{Co}-2$ locus based on genetic allelism tests (Ferreira et al., 2000). Support for a second region conditioning resistance to anthracnose on B11 comes from mapping studies (Beebe et al., 1998; López et al., 2003) where QTL that condition resistance to races 47 (5DOM) and 385 (ANTCL43) map to B11 in the Andean cultivar Chaucha Chuga (G19833). This evidence may suggest the presence of a family of R genes clustered at the $\mathrm{Co}-2$ locus on B11 (Creusot et al., 1999; Geffroy et al., 1998; López et al., 2003).

Breeding value: $\mathrm{Co}-2$ is not a particularly valuable gene given its lack of durability when deployed alone in many countries. In France for example, the resistance conferred by the $\mathrm{Co}-2$ gene was effective for 13 years from 1960 to 1973 (Fouilloux, 1979) and its extensive use in Latin America was reported as 'dangerous' according to Pastor-Corrales and Tu (1989). In addition to the widespread deployment of $\mathrm{Co}$-2 singly (Fouilloux, 1979; Tu, 1992), other factors may have resulted in the loss of this valuable resistance source. Breakdown of resistance caused by the importation of seed infected with new races of anthracnose is known and documented. Seed infected with race 65 (epsilon) was imported into and sold in Michigan (Balardin and Kelly, 1996). Evidence that this race existed previously in adjacent production areas was documented (Tu et al., 1984). Likewise the failure of the $\mathrm{Co}-2$ resistance to race 89 (alpha-Brazil) in Ontario was due to imported seed infected with anthracnose (Tu, 1994) as race 73, present in Michigan, has very similar virulence patterns (Kelly et al., 1994). Similar reports of new anthracnose infections due to imported seed are documented in France (Fouilloux, 1979). In other countries, Co- 2 was deployed without prior knowledge that races already existed in the production area that could overcome the gene (Fouilloux, 1976; Menezes and Dianese, 1988). Inadequate characterization of the races present in a production area may result in the rapid failure of any new genes being deployed in new cultivars. A full characterization of races present in a region or country is essential before specific genes are deployed, since singly deployed resistance genes will fail to provide long-term resistance. To extend the durability of the $\mathrm{Co}-2$ resistance gene in North America where both Andean and Middle American races of the pathogen exist, gene pyramids with alleles at the $\mathrm{Co}-1$ locus have been released in new bean cultivars such as Chinook 2000, Jaguar, Newport, Phantom, and Red Hawk (Beaver et al., 2003).

\section{Locus Co-3}

Origin: The $\mathrm{Co}-3$ gene, originally known as Mexique 1, was first described by Bannerot (1965) in the genotype Mexico 222. The resistance was derived from Mexican germplasm, the specific origin of which is not known. The resistance was shown to be independent of the Co-1 locus (Young and Kelly, 1997b), and the Co-2 gene (Bannerot et al., 1971; Fouilloux, 1976) the only two independent loci described at that time. Interestingly, in an $\mathrm{F}_{2}$ population from the cross Mexico $222 \times$ MSU-7, inoculated with race 7 which generates an $R \times R$ reaction in the parents, a 63:1 ratio ( $p=0.98$ ) of resistant to susceptible individuals was observed. This indicates that three genes for resistance to race 7 were segregating in this cross. The Michigan State University breeding line MSU-7 has been characterized and carries only one anthracnose resistance gene, $\mathrm{Co}-7$, derived from the differential cultivar G 2333 (Vallejo and Kelly, unpublished data). These data suggest that Mexico 222 carries two genes for resistance to race 7 .

Alleles: A second allele at the $\mathrm{Co}-3$ locus, present in the genotype Mexico 227 (now extinct) was reported (Table 2; Fouilloux, 1976, 1979). This locus was one of the first loci conditioning resistance to anthracnose where alleles were described. The second allele in Mexico 227 was not fully characterized; however, according to Fouilloux (1979) it demonstrated weaker activity compared to the first allele. The second allele was overcome by race 31 (kappa, ebnet), whereas the $\mathrm{Co}-3$ gene in Mexico 222 was resistant (Hallard and Trebuchet, 1976). Other alleles at the $\mathrm{Co}-3$ locus have recently been reported in BAT 93 and PI 207262 (Rodríguez-Suárez et al., 2004).

Markers: None identified.

Map location: Allelism tests and genetic linkage studies with $\mathrm{Co}-9$ gene place the $\mathrm{Co}-3$ locus on B4 (Rodríguez-Suárez et al., 2004). In addition, the resistance spectrum of the cultivar Chaucha Chuga to 25 diverse and virulent races of C. lindemuthianum is similar to that of $\mathrm{Co}-3$ (includes races 47, 385 and 521; Beebe, personal communication). QTL were detected on linkage groups B4, B10 and B11 in mapping studies with 'Chaucha Chuga'(López et al., 2003). Three QTL that conditioned resistance to $C$. lindemuthianum isolates $(43 \mathrm{COL}=$ race 385 ; $5 \mathrm{DOM}=$ race 47 ) were detected on $\mathrm{B} 4$ and one QTL mapped to the same region where the Co-9 gene was previously mapped (Geffroy et al. (1999).

Breeding value: The breeding value of the $\mathrm{Co}-3$ locus is very specific to certain locations. 
In some instances, $\mathrm{Co}$-3 affords resistance to highly virulent MA races 3481, 3977 and 3993 from Costa Rica that carry over five virulence genes (Beebe, personal communication). In other countries, particularly Brazil and Mexico, the gene has little or no value due to frequent failure (Alzate-Marin et al., 2001a; Balardin et al., 1997; Gonzalez et al., 1998; Kelly, 2000). In the absence of further information on the reaction to other specific races, breeders would best focus initially on other loci for purposes of resistance breeding. To be effective in resistance breeding, $\mathrm{Co}-3$ should be included as a member of a gene pyramid provided linked markers are available to achieve this objective.

\section{Locus Co-4}

Origin: The Co-4 gene, originally known as Mexique 2, was first described in the genotype TO, derived from the cross of the cultivar Tenderette with the resistant line reported as 'Acapulco' from Mexico (Bannerot, 1965; Fouilloux, 1976, 1979; Hallard and Trebuchet, 1976). The resistance in TO was shown to be independent of the $\mathrm{Co}-1$ locus (Young and Kelly, 1997b), and the Co-2, and Co-3 genes (Fouilloux, 1976, 1979), the only three independent loci described at that time.

Alleles: A second allele, $\mathrm{Co}-4^{2}$, present in the genotype SEL 1308, derived from the highly resistant anthracnose differential cultivar G 2333, has been reported at the $\mathrm{Co}-4$ locus (Tables 1 and 2; Young et al., 1998). The second allele provides greater resistance than the original $\mathrm{Co}-4$ allele and it is recognized among the broadestbased resistance genes described in common bean (Balardin and Kelly, 1998; Silverio et al., 2002). Additional alleles at the $\mathrm{Co}-4$ locus have been identified in the anthracnose differential cultivar PI 207262 (Table 2). Evidence for two independent genes in PI 207262 comes from crosses with the first three differential cultivars, Michelite, MDRK, and Perry Marrow (Gonçalves-Vidigal et al., 1997). A two gene $(15: 1)$ segregation ratio was observed after inoculation with the race 23 (delta) that overcomes the resistance in all three differential cultivars. A three gene ratio (63:1) was observed in the $\mathrm{F}_{2}$ population of the cross PI $207262 \mathrm{x}$ Cornell 49-242, the later carries the $\mathrm{Co}-2$ gene. The genes present in PI 207262 are independent of the $\mathrm{Co}-1$ and $\mathrm{Co}-2$ loci. Additional allelism tests between PI 207262 and TO, G 2333, and SEL1308 confirmed that another allele at the Co-4locus is present in PI207262 (Alzate Marin et al., 2001a, 2002b). Indirect evidence for the presence of other alleles at the $\mathrm{Co}-4$ locus in PI 207262 comes from marker studies. Young et al. (1998) reported that the AS13 marker linked to the $\mathrm{Co}-4^{2}$ allele in SEL 1308 and G 2333 was present in TO (Co-4) and PI 207262. The OC8 marker reportedly linked to the $\mathrm{Co}-4$ allele (Castanheira et al., 1999) is also present in PI 207262. Since PI 207262 has been shown to carry two independent resistance genes (Gonçalves-Vidigal et al., 1997), and is lower in the differential series than $\mathrm{TO}$ (nos. 128 vs. 256 ), the Co-4 allele in PI 207262 must be different than previously reported alleles at the $\mathrm{Co}-4$ locus in TO, G2333 and SEL 1308 (Young et al., 1998).
The Co-4 allele present in PI 207262 must be less broad-based than the original $\mathrm{Co}-4$ in TO, or $\mathrm{Co}-4^{2}$ in SEL 1308. The gene symbol $\mathrm{Co}-4^{3}$ was proposed for the $\mathrm{Co}-4$ allele in PI 207262 (Alzate Marin et al., 2002c). Finally, preliminary evidence from our lab shows that another highly resistant genotype, G 2338, originating from the same region of Mexico (Chiapas) as G 2333, possess a 3-gene resistance pyramid that includes another allele at the $\mathrm{Co}-4$ locus (Vallejo and Kelly, unpublished data).

Markers: Markers linked to the different alleles at the Co-4 locus have been described. RAPD markers linked in coupling and repulsion in TO were reported (de Arruda et al., 2000; Castanheira etal., 1999). SCAR markerSAS13, tightly linked to the $\mathrm{Co}-4^{2}$ allele in SEL 1308, was described by Young et al. (1998) and later confirmed by Alzate-Marin et al. (2001c). These and others markers reported by Awale and Kelly (2001) differ in their specificity to amplify alleles at the $\mathrm{Co}-4$ locus. An open reading frame, $\mathrm{COK}$ 4 , coding for a serine-threonine kinase, with a high degree of similarity to the Pto resistance gene in tomato (Lycopersicon esculentum), has been cloned and shown to be tightly linked $(0.39$ $\mathrm{cM})$ to the resistance phenotype of the $\mathrm{Co}-4^{2}$ allele (Melotto and Kelly, 2001). Single nucleotide polymorphism (SNP) markers and cleaved amplified polymorphic sequence (CAPS) markers for different alleles at the $\mathrm{Co}-4$ locus have been identified and proved to be more effective than SCAR marker in the identification of alleles at the Co-4 locus in common bean (Melotto and Kelly, 2001).

Map location: The Co-4 locus has been mapped to linkage group B8 (Fig. 1) on the integrated map using putatively linked SSR markers developed by Caixeta et al. (2003). Additional evidence comes from work by Mendez de Vigo (2001) who mapped Co-4 to B8 using the SAS13 marker as a probe. Indirect evidence for the presence of $\mathrm{Co}-4$ on $\mathrm{B} 8$ comes from linkage studies with the color genes present in P. vulgaris. Gantet et al. (1991) originally reported a tight linkage $(2.3 \mathrm{cM})$ between the Mexique 2 (Co-4) gene and the Anp (anthocyanins in the pod) gene that produces the purple pod phenotype. The Anp and the Prp (purple pod locus), both produce anthocyanins in bean pods are likely the same locus (Bassett, personal communication). Bassett (1994) reported a tight linkage between purple pod locus Prp and the complex $C$ locus. Given the absence of crossovers in over 4,000 $\mathrm{F}_{2}$ plants, Bassett (1994) proposed the bracket convention [CPrp] to denote the tight linkage between these two genes. The $C$ locus is a complex locus as it also includes the $R$ gene for dominant red color [ $C$ $R]$ (Bassett, 1995, 1996, 1998). The [C R Prp] complex locus is located on B8 (McClean et al., 2002). Further confirmation comes from Miklas et al. (2000a) who mapped the $R$ gene to B 8 and independently Gepts (1999) who also confirmed that the $C$ locus is located on $\mathrm{B} 8$. The presence of the [CR Prp] complex locus on B8, and the reported linkage of $\mathrm{Co}-4$ locus with Anp (Prp) gene, support the location of the $\mathrm{Co}-4$ locus on B8 (Kelly et al., 2003). Finally, the $\mathrm{Co}-4$ locus was physically mapped using fluorescent in situ hybridization (FISH) to the short arm of the bean chromosome 3 that corresponds to linkage group B8 (Melotto et al., 2004).

Breeding value: $\mathrm{Co}-4$ is a complex locus and a very valuable locus depending on which allele is chosen in resistance breeding. The original Co-4 gene is too weak to be valuable in most breeding programs as the allele is overcome by many common races of the anthracnose pathogen in Mexico (Balardin et al., 1997; Gonzalez et al., 1998; Kelly, 2000), whereas the $\mathrm{Co}-4^{3}$ allele in PI 207262 is potentially useful in Brazil (Alzate Marin et al., 2002b, 2003c; Gonçalves-Vidigaletal., 1999). Breeders should focus their attention on the $\mathrm{Co}-4^{2}$ allele as the best resistance source available at the $\mathrm{Co}-4$ locus (Balardin and Kelly, 1998). The Co- $4^{2}$ gene was confirmed to be the only gene in the 3-gene pyramid in G 2333 to afford resistance to the highly virulent race 2047 (Silverio et al., 2002). The SAS 13 marker has proven very useful in MAS for anthracnose resistance (Miklas and Kelly, 2002) except in the improvement of large white fabada beans in Spain where its presence in susceptible cultivars has precluded its use (Ferreira et al., 2000). Since the SAS13 marker is present in cultivars possessing other alleles at the Co-4 locus (Alzate Marin et al., 2002c), other linked markers such as SH18 and SBB14 (Awale and Kelly, 2001) that distinguish between alleles at the $\mathrm{Co}-4$ locus may be more useful in marker-aided breeding depending on the genetic background of the germplasm to be improved. In addition to the linked SCAR markers, SNP and CAPS markers were shown by Melotto and Kelly (2001) to be effective in separating between alleles at the $\mathrm{Co}-4$ locus and could be used in marker-aided breeding.

\section{Locus Co-5}

Origin: The $\mathrm{Co}-5$ gene, originally known as Mexique 3, was first described in the genotype TU derived from the cross of the susceptible cultivar Tenderette x Mexico (Bannerot, 1965; Fouilloux, 1976, 1979; Hallard and Trebuchet, 1976). The resistance in TU was shown to be independent of the Co-1 (Young and Kelly, 1997b), and the Co-2, Co-3 and Co-4 loci (Fouilloux, 1976, 1979), previously described at that time.

Alleles: None confirmed. The Co-5 resistance gene was shown to be the same as/or allelic to the gene(s) in breeding lines TV derived from ('Tenderette' x Cozumel), TX ('Tenderette' $x$ Taxco I), TY ('Tenderette' $x$ Taxco II), and TW ('Tenderette' x Uxmall; Fouilloux, 1976, 1979) and SEL 1360 derived from G 2333 (Young and Kelly, 1996a). Since the Mexican lines described as resistance sources for the $\mathrm{Co}-3$, $\mathrm{Co}-4$ and $\mathrm{Co}-5$ genes came from bean collections made in Mexico and do not represent any known contemporary accession or cultivar, they are no longer available to verify if allelic differences exist. The same allele at the $\mathrm{Co}-5$ locus appears to be present in TU, SEL 1360 and G 2333 (Young and Kelly, 1996a). Since the authors were unable to discriminate between TU and SEL 1360 using different races of the pathogen, they surmised that both genotypes carry the same Co-5 allele (Table 2).

Markers: Markers linked to the Co-5 locus have been reported (Young and Kelly, 1997a). 
Given the difficulty of amplifying the $\mathrm{OAB} 3_{430}$ RAPD marker, a SCAR marker (SAB3) was developed (Vallejo and Kelly, 2001) and other RAPD markers linked to the $\mathrm{Co}-5$ locus have recently been identified (Castanheira et al., 1999). The SAB3 marker was shown to be present in TU, SEL 1360, G 2333 and G 2338 confirming the presence of the $\mathrm{Co}-5$ gene in all four cultivars (Vallejo, unpublished data).

Map location: Unknown, as there is a lack of polymorphism for the SAB3 marker in the BAT 93 and Jalo EEP558 parents of the BJ mapping population.

Breeding value: The Co-5 gene does not appear to have been widely deployed in resistance breeding, althought it is among the most effective genes in a survey of races of C. lindemuthianum from Central America and Mexico (Balardin et al., 1997). The limited use of $\mathrm{Co}-5$ in breeding makes the gene even more valuable to breeders interested in pyramiding independent resistance genes.

\section{Locus Co-6}

Origin: The Co-6 gene was first reported in the cultivar Catrachita derived from the cross of BAT1225 x AB136 (Young and Kelly, 1996a). The resistant parent of 'Catrachita', AB136, first described by Schwartz et al. (1982), carries binary number 1024 in the anthracnose differential series (Melotto et al., 2000a). The Co-6 was confirmed to be present in AB136 as a single dominant gene (Gonçalves-Vidigal et al., 2001; Poletine et al., 2000) conditioning resistance to races 23, 31, 69, and 453 (Gonçalves-Vidigal et al., 1997, 1999, 2001). The Co-6 gene replaces the original symbol ' $\mathrm{Q}$ ' proposed by Gonçalves-Vidigal (1994) for the gene conditioning resistance to race 31 in $\mathrm{AB}$ 136 (Table 2; Poletine et al., 2000).

Alleles: None reported. Possible alleles at the $C o-6$ locus are discussed in relation to the co-8 gene.

Markers: Two sets of RAPD markers linked in coupling and repulsion have been reported to flank the Co-6 locus (Alzate-Marin et al., 1999, 2000; Young and Kelly, 1997a). At present no SCAR markers have been developed for the Co-6 gene.

Map location: The Co-6 locus was mapped to B7 (Fig. 1; Kelly et al., 2003; Mendez de Vigo (2001) using the OPZ04 ${ }_{560}$ marker identified by Alzate-Marin et al. (1999) and the presence of $\mathrm{Z}_{600}$ marker on B7 of the integrated linkage map (Freyre et al., 1998). The Co-6 appears to be located in a region of $\mathrm{B} 7$ flanked by the $P$ (basic color gene) and $P h s$ (phaseolin) genes (Freyre et al. 1998; Kelly et al., 2003) and near to the $E f$ (elongation factor, Adam-Blondon et al. 1994b), and the Co-v locus assigned provisionally as an anthracnose resistance locus by Geffroy (1997).

Breeding value: The Co- 6 offers broadbased resistance to a large number of races of the anthracnose pathogen, particularly those of Andean origin. The gene should be particularly valuable in Brazil (Gonçalves-Vidigal et al., 1997) where it conditioned resistance to all known isolates of $C$. lindemuthianum (Menezes and Dianese, 1998). However, the Co-6 gene is much less effective against MA races of anthracnose that predominate in Central America, Mexico and Ecuador (Balardin et al., 1997; Falconi et al., 2003; Pastor-Corrales et al., 1995). The single gene has not lasted long in Central America where highly virulent races of the pathogen exist (Balardin et al., 1997; Pastor-Corrales et al., 1994) so effective pyramids need to be developed to extend its value in geographic regions where the $\mathrm{Co}-6$ gene has not been previously used.

\section{Locus Co-7}

Origin: The $\mathrm{Co}$-7 locus was first described by Young etal.(1998) as the third independent gene in the anthracnose differential cultivar G 2333. To fully characterize the $\mathrm{Co}-7$ gene, a breeding line (SEL 111) was identified with resistance to race 521 (overcomes $\mathrm{Co}-5$ ), but without the Co- $4^{2}$ gene (absence of SAS13 marker). SEL 111 , assumed to carry two resistance genes ( $\mathrm{Co}-5, \mathrm{Co}-7)$ was crossed to the susceptible cultivar Black Magic and the $\mathrm{F}_{2}$ population was screened separately with races $7,73,449,521$, 1545 to confirm the presence of the two genes and isolate the $\mathrm{Co}-7$ gene in a breeding line. After inoculation with race 73 , the 'Black Magic' $x$ SEL 111 population segregated 3:1 suggesting the presence of one not two genes as expected. Since SEL 111 possesses the Co-5 gene, the second gene must have been overcome by race 73. Evidence that the third gene in G 2333 is defeated by race 73 came from the cross of Rudá (A285; susceptible) x G 2333 (Alzate-Marin et al., 1998). After inoculation with race 73 , a two gene (15:1) ratio was observed suggesting that $G$ 2333 possessed only two independent dominant genes. Since G 2333 was previously shown to possess three genes (Young et al., 1998), the third gene in $\mathrm{G} 2333$, must have been defeated by race 73 . The only two major resistance genes defeated by race 73 are the $\mathrm{Co}-2$ and $\mathrm{Co}-3$ genes. G 2333 does not possess the $\mathrm{Co}-2$ gene since markers linked to $\mathrm{Co}-2$ were absent in $\mathrm{G}$ 2333 and the original $F_{2}$ population inoculated with race 521 indicated the presence of genes other than $\mathrm{Co}-2$, which is overcome by race 521 (Pastor-Corrales et al., 1994). Since the third gene is resistant to race 521 and susceptible to race 73 , the most likely candidate among the known genes is $\mathrm{Co}-3$. To test this hypothesis, a $F_{2}$ population from the cross Mexico $222 x$ MSU-7 (line derived from SEL 111 which carries $\mathrm{Co}$-7 as its only anthracnose resistance gene) was inoculated with race 7 which yields an $R$ $x \mathrm{R}$ reaction in the parents. A 63:1 segregation ratio was observed $(p=0.98)$ which indicates that $\mathrm{Co}-7$ is independent of $\mathrm{Co}-3$ (Vallejo and Kelly, unpublished data). Further allelism tests need to be conducted to confirm that $\mathrm{Co}-7$ is independent of the other anthracnose resistance loci characterized.

Alleles: None reported.

Markers: None reported.

Map location: Unknown.

Breeding value: The breeding potential of the $\mathrm{Co}^{-7}$ is unknown at present. The major resistance gene among the three genes present in G 2333 is $\mathrm{Co}^{-} 4^{2}$ (Alzate Marin et al., 2001c; Silverio et al., 2002; Young et al., 1998), suggesting that the Co-7 may not be a broadly effective resistance gene. Until more information on its resistance pattern is available and/or linked markers are available, the gene is not recommended to breeders as a source of anthracnose resistance.

\section{Locus co-8}

Origin: The co- 8 gene was first described in the genotype AB 136 (Alzate-Marin et al., 1997), as an independent gene from the previously reported $\mathrm{Co}-6$ gene in the same differential cultivar (Gonçalves-Vidigal et al., 1997, 1999; Young and Kelly, 1996a). The recessive co-8 gene was reported in AB136 following inoculation of $190 \mathrm{~F}_{2}$ individuals with race 73 . The lack of $\mathrm{F}_{3}$ progeny data and the proximity of the two genetic ratios (13R:3S dominant: recessive ratio versus $3 \mathrm{R}: 1 \mathrm{~S}$ single dominant gene) puts into question the presence of the recessive $\mathrm{Co}-8$ gene in AB136. Using linked markers the same authors were unable to support the presence of a recessive allele in the same population (AlzateMarin et al., 1999). In other inheritance studies where $\mathrm{AB} 136$ was used as a parent, support for the presence of a recessive gene is lacking (Gonçalves-Vidigal et al., 1997, 1999, 2001; Poletine et al., 2000). All segregating ratios in four $\mathrm{F}_{2}$ populations support the presence of the single dominant Co-6 gene in AB 136 with no evidence for an independent recessive resistance gene. Recessive resistance to anthracnose has been reported in the literature, but in both instances (beta; Cardenas et al., 1964; Muhalet et al., 1981) it appears to result from a reversal of dominance at the multi-allelic $\mathrm{Co}-1$ locus. A similar situation may be occurring at the $\mathrm{Co}-6$ locus in the cultivar $\mathrm{AB} 136$ where the $c o-8$ gene was first reported (Alzate-Marin et al., 2001b). As $c o-8$ is the only recessive resistance allele reported to control anthracnose, the presence of a multi-allelic resistance gene locus should be considered as an alterative explanation for this type of resistance.

Alleles: None reported.

Markers: The OPAZ20 ${ }_{950}$ RAPD marker previously reported linked $(7.1 \mathrm{cM})$ to the $\mathrm{Co}$ 6 gene (Alzate-Marin et al., 2000), was also reported to be linked $(2.2 \mathrm{cM})$ to the $\mathrm{co}-8$ in the cultivar AB 136 (Alzate-Marin et al., 2001b). The data also support the lack of independence of $\mathrm{Co}-6$ and $\mathrm{co}-8$.

Map location: Unknown. The co-8 gene reported on B4 (Gepts, 1999) is in error and should be the $\mathrm{Co}-9$ gene previously mapped to B4 (Geffroy et al., 1999).

Breeding value: In the absence of further genetic data on the $\mathrm{co}-8$ gene, its resistance spectra to anthracnose, or map location to support its independence, breeders should be cautious in attempting to use this putative source of resistance to anthracnose. The fact that the same marker linked to $\mathrm{Co}-6$ is also linked to co- 8 gene suggests the existence of a complex locus at $\mathrm{Co}-6$ and due to dominance relationships at the locus, $c o-8$ could be a recessive allele at the $C o-6$ locus.

\section{Locus Co-9}

Origin: The Co-9 gene, first described by Geffroy et al. (1999) in the genotype BAT 93, provides resistance to four anthracnose races including the highly virulent Andean race 
38. In addition, BAT 93 is resistant to $30+$ races from Colombia, race 89 (alpha-Brazil), Kappa (race 31), Jota, Lambda -mutants from Europe, but is susceptible to C236 (race 141) from Guatemala (Schwartz et al., 1982). The resistance in BAT 93 is provided by one of the genes in the anthracnose differential cultivar PI 207262, one of the four parents of BAT 93 (Rodriguez et al., 1995). Since the resistance pattern in BAT 93 is weaker than that of PI 207262 (Schwartz et al., 1982) it would appear that BAT 93 inherited one of the two genes present in PI 207262 (Gonçalves-Vidigal et al., 1997). The presence of a SCAR marker linked to $C o-9$ in BAT 93 and PI 207262 provided indirect confirmation that the $\mathrm{Co}-9$ gene in BAT 93 originated from PI 207262 (Mendez de Vigo et al., 2002). One of the genes in PI 207262 is the $C o-4^{3}$ allele at the Co-4 locus. The absence of markers linked to alleles at the Co-4 locus in BAT 93 and present in PI 207262 , confirms that the second gene in PI 207262 is Co-9 (Table 2). Studies on the independence of the $\mathrm{Co}-9$ have been conducted using PI207262, not BAT 93, so insights into the uniqueness of $\mathrm{Co}-9$ from all other characterized loci are based on indirect evidence from studies with linked markers. Recent inheritance studies, however, suggest that $\mathrm{Co}-9$ gene in BAT 93 is allelic to the Co-3 locus in Mexico 222 (Rodríguez-Suárez et al., 2004).

Alleles: Three alleles at the $\mathrm{Co}-9$ locus were proposed by Alzate-Marin et al. (2003c). The original Co-9 gene is present in PI 207262 , parent of BAT 93, Co- $9^{2}$ in BAT 93 and a third allele, $\mathrm{Co}-\mathrm{9}^{3}$ in 'Widusa'. Since the $\mathrm{Co}-9$ gene was first described by Geffroy et al. (1999) in BAT 93, precedent is established for the original $\mathrm{Co}-9$ allele in BAT 93 . We believe that there is no evidence to suggest that a different allele is present in PI 207262 parent. The presence of other alleles in 'Widusa' is also supported by Rodríguez-Suárez (personal communication), who demonstrated co segregation of a single resistance gene in 'Widusa' after inoculation with races 65, 73, 102 and 453. The resistance gene was co-localized to B4 with markers linked to the $\mathrm{Co}-9$ locus. This observation, however, is challenged by the existence of segregation in allelism tests between 'Widusa' and BAT 93 (Gonçalves-Vidigal et al., 2003), and 'Widusa' and PI 207262 (Ferreira et al., 2003; Gonçalves-Vidigal et al., 2003) after inoculation with different races of the pathogen. We conclude, based on the work of Rodríguez-Suárez et al. (2004), that multiple alleles are present at the $\mathrm{Co}-9$ locus. The original Co-9 allele is present in both BAT 93 and PI 207262, another is allelic to the $\mathrm{Co}-3$ gene, another appears to be one of the genes in 'Widusa' and others are either allelic or tightly linked to the provisionally assigned Co-y and $\mathrm{Co}-z$ resistance genes present in the Andean parent, Jalo EEP558 in the BJ mapping population (Geffroy et al., 1999).

Markers: Eleven RFLP markers linked to the $\mathrm{Co}-9$ locus were reported (Geffroy et al., 1998). Nine of these markers came from the parent BAT 93, whereas the two other markers at this locus were linked with the $C o-y$ and $C o-z$ resistance gene(s) from the Andean parent in the BJ map. Recently, Mendez de Vigo et al. (2002) reported the presence of SCAR marker SB12 tightly linked $(2.9 \mathrm{cM})$ to the $\mathrm{Co}-9$. The presence of the SCAR marker in PI 207262 indirectly confirmed that the $\mathrm{Co}$ - 9 gene in BAT 93 came from the resistant parent, PI 207262. The absence of the marker in other members of the differential series (Jalo EEP558, Co- 1 ; Cornell 49-242, Co-2; Mexico 222, Co-3; TO, Co-4; 'Widusa', MSU-7, Co-7; and G 2333, Co-42, Co-5, Co-7) and other genotypes (Vallejo, unpublished data) supports the independency of the $\mathrm{Co}-9$ from previously characterized loci. Data with linked markers do not preclude, however, independence from other alleles or linked genes at the Co-3 locus.

Map location: The Co-9 locus in BAT 93 was mapped to linkage group B4 on the integrated bean map (Fig. 1; Geffroy et al., 1999). Using SCAR markers linked to Co-9 and $U r-5$ (Melotto and Kelly, 1998), Mendez de Vigo et al. (2002) confirmed the location of $\mathrm{Co}-9$ on B4. The Co-9 gene appears to be located at the end of linkage group B4 in a region of the map where two putative Andean resistance genes, $C o-y$ and $C o-z$ reside. The fact that these putative genes came from the Andean parent, 'Jalo EEP558' mapped next to the Co-9 gene from BAT 93, was presented as evidence for an ancestral resistance gene cluster at this locus (Geffroy et al., 1999). Given that Jalo EEP558 was shown to carry a single major resistance gene, Co-1 (Vallejo, unpublished data), that mapped to $\mathrm{B} 1$, the presence of the two putative resistance genes $C o-y$ and $\mathrm{Co}-\mathrm{z}$ on B4 next to Co-9 is not supported by inoculation studies reported in the literature. Race 38, used by Geffroy et al. (1999) is a highly virulent Andean race with the ability to overcome the resistance in 'Jalo EEP558' (Vallejo et al., 2003) and other alleles at the Co- 1 locus (Melotto and Kelly, 2000), whereas Co-9 in BAT 93 is resistant to race 38 . The Co-9 gene reported on B2 (Gepts, 1999) is in error and should be the provisionally assigned gene $\mathrm{Co}-u$ (Geffroy, 1997) that mapped to B2 (Kelly et al., 2003). Mention of Co-9 on B7 (Miklas et al., 2000a) is in error and should be the provisionally assigned gene $C o-v$ (Geffroy, 1997) that mapped to B7 (Kelly et al., 2003). QTL for anthracnose resistance were recently mapped to B4 (Geffroy et al., 2000; López et al., 2003) and may represent the colocalization of genes with partial effects on anthracnose resistance. For a more complete discussion of co-localization of QTL and major resistance genes the reader is referred to Kelly and Vallejo (2004).

Breeding value: The Co-9 gene has very specific breeding value against Andean races of anthracnose, but is susceptible to weaker MA races such as race 65 (epsilon) and 69 (Poletine et al., 1999), whereas other workers have shown that BAT 93 is resistant to race 65 (Alzate-Marin et al., 2003c). Since PI 207262 is overcome by many anthracnose races from Mexico and Guatemala (Gonzales et al., 1998; Kelly, 2000; Schwartz et al., 1982), the Co-9 is not a widely effective resistance source. Breeders should give preference to other MA broader-based resistance sources and may con- sider using $C o$ - 9 only to diversify the resistance in gene pyramids because of its independence and potential value in controlling virulent Andean races such as 31 and 38 .

\section{Locus Co-10}

Origin: The Co-10 gene present in the Brazilian black bean cultivar Ouro Negro previously known as Honduras 35, was first described as an independent locus from the previously characterized anthracnose resistance genes: Co-1 (MDRK), Co- $1^{2}$ ('Kaboon'), Co- $1^{3}$ ('Perry Marrow'), 'Widusa', Co-2 (Cornell 49-242), Co-3 (Mexico 222), Co-4 (TO), Co-42 (SEL 1308), Co- $4^{3}$ and $C o-9$ (PI 207262), Co-5 (SEL 1360 ), and Co-6 (AB 136) by Alzate-Marin et al. (2003b). Since neither the $\mathrm{Co}-7$ nor $\mathrm{co}-8$ loci were fixed or available in a single genetic background for testing at the time of this study, allelism tests were not conducted (Alzate-Marin et al., 2003b).

Alleles: None reported.

Markers: The Co-10 locus is linked at 12 $\mathrm{cM}$ from the F10 RAPD marker (Alzate-Marin et al., 2003b).

Map location: The Co-10 gene is linked to the sameF10 RAPD marker that was also linked to the rust resistance locus in 'Ouro Negro' (Alzate-Marin et al., 2003b). The F10 marker linked to the $U r-5$ rust resistance gene (Haley et al., 1993) mapped to the B4 (Kelly et al., 2003) adjacent to the $\mathrm{Co}-9$ locus. In the cross of 'Ouro Negro' (Co-10) x PI 207262 (Co-4 $4^{3}$ Co-9), Alzate-Marin et al. (2003b) demonstrated clear independence for a three-gene model, suggesting that if $\mathrm{Co}-9$ and $\mathrm{Co}-10$ reside on $\mathrm{B} 4$, they are sufficiently separate to be independent. In a related study on rust resistance loci, AlzateMarin et al. (2002b) showed independence between the $U r-5$ locus and the rust resistance gene block in 'Ouro Negro' both previously assigned to B4 (Kelly et al., 2003). The Co-10 gene reported on B7 (Gepts, 1999) is in error. The locus had been provisionally assigned the symbol Co-v (Geffroy, 1997) and the anthracnose loci on B7 have been assigned to the Co-6 and Co-v genes (Kelly et al., 2003).

Breeding Value: The potential of the Co- 10 gene is unknown outside of Brazil. Co-10 confers resistance to $C$. lindemuthianum races: 23 , $64,67,73,81,83,87,89,95,102,117,119,343$, 453, 1033, 1545 and 1600 common in Brazil (Alzate-Marin et al., 2003b). If the races listed above were problematic in other regions, the $\mathrm{Co}$ 10 gene should be considered by bean breeders, once more-tightly-linked markers are available to assist in breeding resistance pyramids that would include the Co-10 gene.

\section{Anthracnose Resistance Loci}

Majorgene resistance to anthracnose follows a pattern similar to that described for resistance to bean common mosaic virus (BCMV) in common bean, where five independent loci condition resistance to BCMV and multiple alleles are present at two loci (Drijfhout, 1978; Kelly et al., 1995, Miklas et al., 2000b). Similar genetic systems function in other crops such as wheat (Triticum aestivum), where 50 leaf rust $\mathrm{Lr}$ genes have been identified (McIntosh 
et al., 1995) and 28 powdery mildew $P m$ genes display a multi-allelic series (Zeller and Hsam, 1998). In the case of anthracnose, resistance is localized at nine independent loci in the bean genome as the $\mathrm{Co}-3 / \mathrm{Co}-9$ genes are allelic. With the exception of those loci ( $\mathrm{Co}-5, \mathrm{Co}-7, \mathrm{Co}-8)$ not yet mapped, all other loci are mapped to different linkage groups, although $\mathrm{Co}-3 / \mathrm{Co}-9$ and Co-10 reside on B4 but appear to be unlinked (Alzate-Marin et al., 2003b; Rodríguez-Suárez et al., 2004). Multiple alleles (or tightly linked loci) have been shown to exist at a number of these loci: Co-1 (Alzate-Marin et al., 2003a; Gonçalves-Vidigal et al., 2003; Melotto and Kelly, 2000); Co-3 (Fouilloux, 1979; Rodríguez-Suárez et al., 2004); Co-4 (Alzate Marin et al., 2002c; Young et al., 1998); and possibly the $\mathrm{Co}-2$ locus (Muhalet et al., 1981). Recently described resistance genes such as in the Andean genotypes A193, 'Diacol Calima' and Jalo EEP558 appear to carry alleles at the Co-1 locus (Mendoza et al., 2001; Schwartz et al., 1982; Vallejo et al., 2003). Other loci such as the recessive co- 8 gene, for example, lack insufficient genetic evidence to support their separate existence. The independence of nine anthracnose resistance genes distributed across the genome offers bean breeders the unique opportunity to pyramid complementary resistance genes (Duvick, 1996) and, in certain cases based on its resistance spectrum, to choose the most effective allele at different loci, as the most effective strategy in breeding for durable resistance to anthracnose (Kelly and Miklas, 1998).

\section{Resistance Gene Clusters}

An increasingly large body of scientific literature supports the theory that resistance genes are clustered within plant genomes (Meyers et al., 1998). Similar to the resistance gene clusters reported in other crops (Michelmore and Meyers, 1998), the resistance genes for anthracnose are clustered with other resistance genes on different linkage groups in the bean genome (Kelly et al., 2003). As evidence from many crops continues to accumulate, the underlying premise that these highly conserved regions in the plant genome may provide complementary roles in resistance to a range of pathogens and pests alike. Genome efficiency is implied by such arrangements. Gene clusters of anthracnose and $U r$-rust resistance genes are located on linkage groups B1, B4 and B11 (Fig. 1). The Andean resistance genes for anthracnose, Co-1, and rust, $U r-9$, cluster on $\mathrm{B} 1$, whereas MA genes, Co-3/Co-9 and $U r-5$, cluster on B4 and other MAgenes, Co-2 and Ur-3/Ur-11, cluster on B11 (Kelly et al., 2003). Despite the recent evidence of gene clusters in common bean based on mapping studies of resistance genes (Kelly et al., 2003; Miklas et al., 2000a), there is a paucity of similar information from more traditional genetic studies, which begs the question "Why are gene clusters so readily uncovered in mapping studies, not apparent in traditional genetic inheritance studies which have under-girded resistance breeding for decades?" Linkage between rust and anthracnose resistance loci on B1, B4 and B11 should facilitate simultaneous selection for resistance to both diseases but there are no conclusive results from breeding studies to support this idea. Might the gene clusters be so large that recombination can easily occur within the cluster? Evidence exists that genetic recombination occurs at the $U r-5$ resistance gene block in the common bean genotype B-190. Resistance to individual rust races in the bean line B-190 is conditioned by single dominant genes linked in coupling that appear to be inherited as a complex linkage block (Stavely, 1984a). The linkage block in B-190, known as the $U r-5$ locus (Kelly et al., 1996), behaves as a major Mendelian factor that has been tagged (Haley et al., 1993; Melotto and Kelly, 1998), mapped to B4 (Gepts, 1999; Kelly et al., 2003; Miklas et al., 2000a) and successfully integrated into a range of bean genotypes (Freytag et al., 1985; Stavely, 2000). Confirmation that recombination has occurred within the closely linked gene block was based on the inoculation of $160 \mathrm{~F}_{2}$ individuals with eight races of rust. A total of 144 individuals exhibited the phenotype of the parents to all eight races, whereas an additional 16 were resistant to one or more races and susceptible to the remainder. Two of the seven resistance genes appeared to be allelic, but the rest of the resistance genes were closely linked to one another (Stavely, 1984).

In the case of anthracnose resistance genes, clusters have been reported at the $\mathrm{Co}-2$ and $\mathrm{Co}-9$ loci (Creusot et al., 1999; Ferrier-Cana et al., 2003; Geffroy et al., 1999). The breakdown of resistance conferred by $\mathrm{Co}-2$, a gene that confers resistance to a wide variety of races, may have been aggravated by the disruption of the resistance gene cluster. In sunflower $(\mathrm{He}$ lianthus annuus), the P16 locus was believed to be race-non-specific because it conferred resistance to all known races at the time of the study. Recombination within the cluster was detected, however, in $150 \mathrm{~F}_{3}$ progeny inoculated with 5 races, and two genetically distinct regions were identified which conferred race-specific resistance (Vear et al., 1997). Likewise, five bean genotypes (Ecuador 299, Mexico 235, NEP-2, 'Aurora', 51051) that each possess the $U r$-3 gene display different reaction to 20 rust races (Stavely, 1984b) suggesting that certain genotypes with the $U r-3$ have lost members of the linked resistance gene cluster that constitute the $U r-3$ gene cluster due to recombination events during the introgression of the gene into different genetic backgrounds. Similarly, resistance conferred by $\mathrm{Co}-2$ could have broken down due to recombination events within the locus thus disrupting the functionality of closely linked resistance genes. Although multiple alleles at other anthracnose resistance loci have been reported, the possibility that there are multiple closely linked genes in a cluster is not excluded by the allelism test. Therefore, it is very likely that gene clusters can exist at loci where multiple alleles have been previously identified. Allelism studies detect only linkage between two loci being tested, therefore one can only conclude whether two loci are less than or greater than $50 \mathrm{cM}$ apart. This test for independence does not detect recombination events that occur within the putative cluster, because only one anthracnose race is typically used in the analysis. Despite the evidence of resistance gene clusters, practical breeding for resistance may not be greatly facilitated by this knowledge. The value of mapping for breeders is not the associated traits that might be carried along in crossing, but the knowledge of independence of resistance genes should facilitate the pyramiding of different genes to enhance resistance.

\section{Anthracnose Differential Series}

The twelve-cultivar differential series developed by Pastor-Corrales (1991) has been invaluable in accessing the pathogenic variability of $C$. lindemuthianum worldwide (Table 1; Melotto et al., 2000a). In addition, the differential set has served as a valuable source of resistance genes for breeding purposes. In selecting members to include in the differential series, consideration was given to choosing genetically diverse cultivars with differentiating reactions to isolates of $C$. lindemuthianum, to provide effective separation of variability present in the pathogen, whereas less consideration was given to the genetic or gene pool background of the cultivars. Five genotypes (MDRK, Cornell 49-242, Mexico 222, TO, TU) were selected, as they possessed known independent resistance genes (Tables 1 and 2). In addition, the choice of 'Michelite' as the universal susceptible was interesting, as it is known to possess some level of resistance. A number of $C$. lindemuthianum races have since been classified as race 0 due to their inability to pathogenize any member of the differential series including 'Michelite' (Sicard et al., 1997). These races could carry additional avirulence factors but they cannot be separated with the current differential set of cultivars. The genetics of the seven other differential cultivars was unknown at the time of their selection for inclusion in the differential set. Given our current knowledge of the genetics of the 12 differential cultivars, consideration should be given to modifying the differential set to include only genotypes with single resistance genes and/or add new sources of genetic resistance primarily from the Andean gene pool, which is underrepresented in the current differential set. The paucity of different resistance genes of Andean origin represented in the differential series is supported by Beebe et al. (2001) who suggested that the lack of diversity in Andean bean landraces, based on molecular marker profiles, may be the result of limited domestication events in the Andean region. To date, we know the following: Ten different loci control anthracnose resistance in common bean. At least three loci are multi-allelic and differ in their effectiveness against a broad array of virulent races. In some instances a degree of dominance has been demonstrated between alleles at the $\mathrm{Co}-1$ locus, for example. Certain differential genotypes such as 'Perry Marrow', PI207262, and G2333 carry multiple resistance genes that confound the analysis of the resistance spectrum of individual genes. Other genotypes such as, AB 136, Mexico 222 and 'Widusa', may carry additional resistance genes, as the genetic evidence for complementary three gene models (57:7 or 61:3) is common throughout the literature (Alzate-Marin et al., 2002b; Cardenas 
et al., 1964; Ferreira et al., 2003; Melotto and Kelly, 2000; Muhalet et al., 1981). The existence of complementary resistance raises the possibility that bean genotypes carry resistance loci that behave as partial resistance in certain genetic backgrounds possibly detectable by QTL analysis (López et al., 2003). These loci that confer partial resistance could become detectable as major gene resistances in crosses with other genotypes that carry complementary partial resistance loci. QTL analysis has permitted the identification of regions of the genome that confer partial resistance to anthracnose. Geffroy et al. (2000) identified 10 putative QTL scattered across the genome contributing from 11-76\% of the phenotypic variation (Fig. 1). Some of the QTL are race-specific and co-localize with other anthracnose resistance genes or defense response genes. This analysis was conducted using two strains of anthracnose that produce differential symptoms that could be measured on the two parental lines (BAT 93 and Jalo EEP558) and the disease reaction on leaf, stem and petiole tissues of 77 RILs were measured. Although prudent pyramiding of resistance genes and deployment of appropriate resistance gene combinations has proven to be an adequate method of anthracnose control, the addition of QTL that confer partial resistance offers breeders additional tools in selecting for durable resistance.

One of the unresolved anomalies is the number of resistance gene(s) present in the differential cultivar Widusa, a MA snap bean cultivar from Europe (Drijfhout and Davis, 1989; Myers personal communication) with the binary number of 16 (Tables 1 and 2). Two reports confirm that 'Widusa' carries a single dominant gene for resistance (3R:1S; Alzate-Marin et al., 2002a; Gonçalves-Vidigal et al., 2003), whereas a third study showed that Widusa carries two genes, one dominant and one recessive (13R:3S) after inoculation with race 38 (Ferreira et al., 2003). In all cases the susceptible parent in crosses with 'Widusa' (R) was different as were the races chosen to test for resistance in 'Widusa' (Table 3). Such results are not unexpected when using different pathogenic races as one race may be virulent and defeat the second gene in the resistant cultivar resulting in a different segregation ratio. In the case of G 2333 with three resistance genes, 1-, $2-$, and 3-gene segregation ratios have been reported depending on the race of the anthrac- nose pathogen used to inoculate the different segregating populations (Pastor-Corrales et al., 1994; Poletine et al., 2000; Silverio et al., 2002; Young et al., 1998). If one assumes that 'Widusa' carries two major genes for resistance, the problem arises when attempting to confirm which of the genes is complementary to other known resistance genes in the allelism tests. As a result of complementation testing, GonçalvesVidigal et al.(2003) has suggested that 'Widusa' carries an allele at $\mathrm{Co}-1$ (MDRK); Ferreira et al., (2003) suggests that 'Widusa' carries alleles at three different loci, Co-4 (TO), Co-6 (AB136) and also with 'Michelite' (no locus identified); and Alzate-Marin et al. (2003c) suggests the 'Widusa' carries an allele at Co-9 (BAT 93) supported by lack of segregation data in a cross with PI 207262 which also possesses the Co9 loci; and in mapping studies with multiple races 65, 73, 102 and 453 (Rodríguez-Suárez, personal communication). To add to the confusion, clear segregation suggesting independence has been demonstrated in allelism tests between 'Widusa' and TO (Alzate-Marin et al. 2002a; Gonçalves-Vidigal et al., 2003); 'Widusa' and BAT 93 (Gonçalves-Vidigal et al., 2003); and 'Widusa' and PI 207262 (Ferreira et al., 2003; Gonçalves-Vidigal et al., 2003). Although individual researchers use different races, there is an assumption that the races are universally similar in pathogenicity but there has been a lack of correspondence between the results of BAT 93 (and PI 207262) inoculated with race 65 . Alzate-Marin et al., (2003c) reported an incompatible reaction whereas GonçalvesVidigal (personal communication) observed a compatible reaction. Additional studies are needed to resolve these anomalies, but the authors suggest that, in the future, allelism tests be conducted with the same race of the bean anthracnose fungus that was used initially to confirm the existence of a particular resistance gene as different virulent genes in the pathogen generate different segregation patterns in host populations.

\section{New Anthracnose Resistance Genes}

As new resistance sources are identified, breeders need to verify their independence from previously described loci, either through tests of allelism or map location based on linked markers. To reduce the confusion of assigning gene symbols and map locations to new resistance sources, the authors wish to propose a simplified system to verify independence, as the task of conducting ten separate allelism tests is formidable. Researchers should first screen their unknown resistance genotype with markers linked to other known resistance genes before undertaking any allelism tests. If markers linked to a specific resistance locus were detected in the unknown source, then crosses would only need to be made with genotypes known to carry alleles at that locus. For example, if the SAS13 marker were present in the unknown genotype after screening, one would only have to cross with genotypes known to carry alleles at the $\mathrm{Co}-4$ locus. Allelism tests would be conducted by selecting a race of the pathogen that is incompatible on both the unknown source and the genotype with an allele at the $\mathrm{Co}-4$ locus. If markers linked to known anthracnose genes are not detected in the unknown source, then breeders should start with crosses to one selected individual genotype for each $\mathrm{Co}$-gene shown in Table 2, rather than with all members of the differential series in Table 1. Using these genotypes would help avoid duplication with different alleles at the same locus and simplify inheritance studies by using genotypes that carry single genes. Likewise similar informed choices of genotypes from the same gene pool origin of the unknown source ought to help reduce the number of crosses that need to be made. Determining if a new allele exists at a locus would require comparative screening with a diverse range of anthracnose races to detect differences in disease reactions. Only when a new independent locus is detected or allele identified, a new gene symbol should be proposed. Researchers are requested to validate proposed new gene symbols for anthracnose resistance with the Genetics Committee of the Bean Improvement Cooperative (BIC; www.css.msu.edu/bic) before publication to prevent the duplication that has occurred in the past. A similar strategy has also been proposed to simplify the number of allelism tests needed to detect independence between rust resistance genes in common bean (Steadman et al., 2002).

\section{Anthracnose Resistance Mapped Loci}

Some anomalies exist in the published literature regarding the location and naming

Table 3. Allelism tests conducted in segregating populations between 'Widusa' and other differential bean cultivars

\begin{tabular}{|c|c|c|c|c|c|c|c|}
\hline $\begin{array}{l}\text { Widusa } \mathrm{x} \\
\text { Differential }\end{array}$ & $\begin{array}{l}\text { Resistance } \\
\text { genes }\end{array}$ & Race $^{z}$ & $\begin{array}{l}\text { Observed } \\
\mathrm{R} \text { to } \mathrm{S} \text { ratio }\end{array}$ & $\begin{array}{l}\text { Expected } \\
\mathrm{R} \text { to } \mathrm{S} \text { ratio }\end{array}$ & $\chi^{2}$ & $P$ & Reference \\
\hline$\overline{\text { MDRK }}$ & Co-1 & 65 & $200: 0$ & --- & --- & --- & Gonçalves-Vidigal et al., 2003 \\
\hline Michelite & --- & 38 & $116: 0$ & --- & --- & --- & Ferreira et al., 2003 \\
\hline AB 136 & Co-6 & 38 & $236: 0$ & --- & --- & --- & Ferreira et al., 2003 \\
\hline TO & Co-4 & 38 & $114: 0$ & --- & --- & --- & Ferreira et al., 2003 \\
\hline TO & & 65 & $119: 13$ & $15: 1$ & 2.917 & 0.09 & Alzate-Marin et al., 2002a \\
\hline TO & & 7 & $174: 12$ & $15: 1$ & 0.013 & 0.92 & Gonçalves-Vidigal et al., 2003 \\
\hline TO & & 73 & 200:11 & $15: 1$ & 0.387 & 0.53 & Gonçalves-Vidigal et al., 2003 \\
\hline SEL 1308 & $\mathrm{Co}-4^{2}$ & 65 & $124: 4$ & $15: 1$ & 2.133 & 0.14 & Alzate-Marin et al., 2002a \\
\hline PI 207262 & $\mathrm{Co}-4^{3}+\mathrm{Co}-9$ & 65 & 170:0 & --- & --- & --- & Alzate-Marin et al., 2001a \\
\hline PI 207262 & & 38 & $303: 12$ & $61: 3$ & 0.544 & 0.46 & Ferreira et al., 2003 \\
\hline PI 207262 & & 73 & $352: 6$ & $63: 1$ & 0.029 & 0.86 & Gonçalves-Vidigal et al., 2003 \\
\hline BAT 93 & Co- 9 & 65 & $78: 0$ & --- & --- & --- & Alzate-Marin et al., 2003c \\
\hline BAT 93 & & 7 & 229:17 & $15: 1$ & 0.183 & 0.67 & Gonçalves-Vidigal et al., 2003 \\
\hline
\end{tabular}

${ }^{2}$ The choice of race for inoculation was made to generate an $\mathrm{R} \times \mathrm{R}$ reaction in the different segregating populations. 
of certain anthracnose resistance genes ( $\mathrm{Co}-7$, $\mathrm{Co}-8, \mathrm{Co}-9$, and $\mathrm{Co}-10$ ). These discrepancies have resulted primarily from assigning a gene symbol when one already existed rather than from a map location error. The map locations are firm so the authors have reassigned gene symbols to the loci in question based on the most recent bean map (Kelly et al., 2003). For example: Map location of Co-8 on B4 (Gepts, 1999) was reassigned to $\mathrm{Co}-9$; $\mathrm{Co}-9$ on $\mathrm{B} 2$ (Gepts, 1999) was reassigned to $\mathrm{Co}-u$; $\mathrm{Co}-9$ on B7 (Miklas et al., 2000a) was reassigned to $\mathrm{Co}-\mathrm{v}$; and $\mathrm{Co}-10$ on B7 (Gepts, 1999) was reassigned to $\mathrm{Co}-v$ (Kelly et al., 2003). Breeders should first consider the map location(s) of loci with provisional symbols in attempting to finalize the mapping of $\mathrm{Co}-5$ and $\mathrm{Co}-7$ loci and/or new loci that might be detected later. These include Co- $u$ on B2, Co-v on B7 next to Co-6, and the QTL mapped to B3 and B10 (Beebe et al., 1998; Geffroy, 1997; Geffroy et al., 2000; Kelly et al., 2003; López et al., 2003). Loci with provisional symbols were assigned map locations, although full allelism tests were not conducted to assure their independence. These symbols were assigned letter codes as putative new specificities (Geffroy, 1997; Geffroy et al., 1999). A number of these provisional loci coincide with known anthracnose resistance loci based on map locations (Kelly et al., 2003). For example: $\mathrm{Co}-\mathrm{x}$ and $\mathrm{Co}-\mathrm{w}$ coincide with $\mathrm{Co}-\mathrm{I}$ on $\mathrm{B} 1 ; \mathrm{Co}-y$ and $\mathrm{Co}-z$ coincide with $\mathrm{Co}-3 / \mathrm{Co}-9$ on B4; and Co-v coincides with $\mathrm{Co}-6$ on $\mathrm{B} 7$ (Fig. 1). QTL for resistance were also reported on these same linkage groups (Geffroy et al., 2000; López et al., 2003). Actual overlapping locations were not expected as these loci were mapped in different labs and populations, but the coincidence suggests that they may represent the same region where major anthracnose resistance genes reside in the bean genome.

\section{Conclusions}

The review illustrates that the apparent variability for resistance to anthracnose in common bean is not as extensive as first thought. In fact many resistance genes appear to be members of allelic series as was demonstrated at the $\mathrm{Co}$ 1, $\mathrm{Co}-3, \mathrm{Co}-4$, and $\mathrm{Co}-9$ loci or as resistance gene clusters located on linkage group B4 for example. Multiallelic series and gene clusters limit the breeders' choice of useful genes in breeding for anthracnose resistance. Mapping has confirmed the location of most major resistance genes conferring resistance to anthracnose and provided opportunities for gene pyramiding to develop more durable resistance to the high variable pathogen, $C$. lindemuthianum. It is interesting that only one Andean resistance locus has been identified and that five loci $(\mathrm{Co}-3$, $\mathrm{Co}-4, \mathrm{Co}-5, \mathrm{Co}-7, \mathrm{Co}-9$ ) are of Mexican origin. New sources of resistance need to be sought to diversify the resistance spectrum of future bean cultivars. The authors recommend that bean breeders evaluate the potential for stable resistance not only in the primary gene pool of $P$. vulgaris but seek potential new and novel sources of resistance in the secondary gene pool as suggested by Muhuku et al. (2002). In closing, no anthracnose resistance genes have been cloned in common bean, so more work is needed towards the elucidation of the molecular mechanisms behind resistance. On the pathogen side, research is needed to confirm the gene-for-gene model and to characterize the plant/pathogen (Phaseolus vulgaris/Colletotrichum lindemuthianum) interaction at the molecular level.

\section{Literature Cited}

Adam-Blondon, A.F., M. Sevignac, H. Bannerot, and M. Dron. 1994a. SCAR, RAPD and RFLP markers linked to a dominant gene (Are) conferring resistance to anthracnose. Theor. Appl. Genet. 88:865-870.

Adam-Blondon, A.F., M. Sevignac, D. Dron, and H. Bannerot. 1994b. A genetic map of common bean to localize specific resistance genes against anthracnose. Genome 37:915-924.

Alzate-Marin, A.L., K.M. Arruda, E.G. de Barros, and M.A. Moreira. 2002a. Allelism studies for anthracnose resistance genes of common bean cultivar Widusa. Annu. Rpt. Bean Improv. Coop. 45:110-111.

Alzate-Marin, A.L., K.M. Arruda, E.G. de Barros, and M.A. Moreira. 2003a. Allelism studies for anthracnose resistance genes of common bean cultivar AND 277. Annu. Rpt. Bean Improv. Coop. 46:173-174.

Alzate-Marin, A.L., G.S. Baia, T.J. de Paula Junior, G.A. de Carvalho, E.G. de Barros, and M.A. Moreira. 1997. Inheritance of anthracnose resistance in common bean differential cultivar AB 136 Plant Dis. 81:996-998.

Alzate-Marin,A.L., M.R. Costa, K.M.Arruda,E.G.de Barros, and. M.A. Moreira. 2003b. Characterization of the anthracnose resistance gene present in Ouro Negro (Honduras 35) common bean cultivar. Euphytica 133:165-169.

Alzate-Marin, A.L., K.S. de Almeida, E.G. de Barros, and M.A. Moreira. 2001a. Preliminary results of allelism studies for anthracnose resistance genes of common bean cultivar PI 207262. Annu. Rpt. Bean Improv. Coop. 44:113-114.

Alzate-Marin, A.L., K.S. de Almeida, E.G. de Barros, and M.A. Moreira. 2001b. Identification of a recessive gene conferring resistance to anthracnose in common bean lines derived from the differential cultivar AB 136. Annu. Rpt. Bean Improv. Coop. 44:117-118.

Alzate-Marin, A.L., M.A. de Morais Silva, M.A. Moreira, and E.G. de Barros. 2002b. Inheritance of anthracnose resistance genes of common bean cultivar PI 207.262. Annu. Rpt. Bean Improv. Coop. 45:112-113.

Alzate-Marin, A.L., M.A. de Morais Silva, M.A Moreira, and E.G. de Barros. 2002c. Validation of RAPD markers linked to $\mathrm{Co}-4$ anthracnose resistance alleles in common bean cultivar PI 207.262. Annu. Rpt. Bean Improv. Coop. 45:114-115.

Alzate-Marin, A.L., M.A. de Morais Silva, E.J. de Oliveira, M.A. Moreira, and E.G. de Barros. 2003c. Identification of the second anthracnose resistance gene present in the common bean cultivar PI 207.262. Annu. Rpt. Bean Improv. Coop. 46:177-178.

Alzate-Marin, A.L., H. Menarim, G.S. Baia, T.J. de Paula Junior, K.A. de Souza, M.R. da Costa, E.G. de Barros, and M.A. Moreira. 2001c. Inheritance of anthracnose resistance in the common bean differential cultivar G 2333 and identification of a new molecular marker linked to the $\mathrm{Co}-4^{2}$ gene. J. Phytopathology 149:259-264.

Alzate-Marin, A.L., H. Menarim, J.M. Chagas, E.G. de Barros, and M.A. Moreira. 2000. Identification of RAPD marker linked to $\mathrm{Co}-6$ anthracnose resistance gene in common bean cultivar $\mathrm{AB} 136$.
Genet. Mol. Biol. 23:633-637.

Alzate-Marin, A.L., H. Menarim, M.C. de Arruda, G.A. de Carvalho, T.J. de Paula Junior, E.G. de Barros, and M.A. Moreira. 1998. Inheritance of anthracnose resistance in common bean differential cultivars TO, G 2333, and AB 136. Annu. Rpt. Bean Improv. Coop. 41:167-168.

Alzate-Marin, A.L., H. Menarim, G.A. de Carvalho, T.J. de Paula Junior, E.G. de Barros, and M.A Moreira. 1999. Improved selection with newly identified RAPD markers linked to resistance gene to four pathotypes of Colletotrichum lindemuthianum in common bean. Phytopathology 89:281-285.

Andrus, C.F. and B.L. Wade. 1942. The factorial interpretation of anthracnose resistance in beans. USDA Tech. Bull. No. 310:1-29.

Awale, H.E. and J.D. Kelly. 2001. Development of SCAR markers linked to $\mathrm{Co}-4^{2}$ gene in common bean. Annu Rpt. Bean Improv. Coop. 44:119-120.

Balardin, R.S., A. Jarosz, and J.D. Kelly. 1997. Virulence and molecular diversity in Colletotrichum lindemuthianum from South, Central and North America. Phytopathology 87:1184-1191.

Balardin, R.S. and J.D. Kelly. 1996. Identification of Race 65-epsilon of bean anthracnose ( $\mathrm{Col}$ letotrichum lindemuthianum) in Michigan. Plant Dis. 80:712.

Balardin, R.S. and J.D. Kelly.1998. Interaction among races of Colletotrichum lindemuthianum and diversity in Phaseolus vulgaris. J. Amer. Soc. Hort. Sci. 123:1038-1047.

Bannerot, H. 1965. Résults de l'infection d'une collection de haricots par six races physiologiques d'anthracnose. Ann. de Amélior. des Plantes (Paris) 15:201-222.

Bannerot, H., M. Derieux, and G. Fouilloux. 1971. Mise en évidence d'un second gène de résistance totale a l'anthracnose chez le haricot. Ann. de Amélior. des Plantes (Paris) 21:83-85.

Barrus, M.F. 1911. Variation of cultivars of beans in their susceptibility to anthracnose. Phytopathology 1:190-195.

Barrus, M.F. 1915. An anthracnose-resistant red kidney bean. Phytopathology 5:303-311.

Barrus, M.F. 1918. Varietal susceptibility of beans to strains of Colletotrichum lindemuthianum (Sacc. \& Magn.) B. \& C. Phytopathology 8:589-605.

Bassett, M.J. 1994. Tight linkage of purple pod character and the complex $C$ locus in common bean. J. Hered. 85:288-290.

Bassett, M.J. 1995. A new recessive allele at the $C$ locus for seed coat color in common bean. J.Amer. Soc. Hort. Sci. 120:896-899.

Bassett, M.J. 1996. A complex C region genotype $[? R]$ that with $G B v^{\text {lae }}$ produces dark seal-brown seedcoat color in common bean. J. Amer. Soc. Hort. Sci. 121:594-598.

Bassett, J.M. 1998. A test cross protocol for determining the genotype of dark red seedcoat colors in common bean. J. Amer. Soc. Hort. Sci. 123:1048-1052.

Beaver, J.S., J.C. Rosas, J. Myers, J. Acosta, J.D. Kelly, S. Nchimbi-Msolla, R. Misangu, J. Bokosi, S. Temple, and D.P. Coyne. 2003. Contributions of the Bean/Cowpea CRSP to cultivar and germplasm development in common bean. Field Crops Res. 82:87-102.

Beebe, S.E., F. Pedrazo, M. Rojas, J. Gutierrez, and J. Tohme. 1998. A genetic map of common bean combining RFLP, RAPD, SCAR and AFLP markers. Annu. Rpt. Bean Improv. Coop. 41:95-96.

Beebe, S., J. Rengifo, E. Gaitan, M.C. Duque, and J. Tohme. 2001. Diversity and origin of Andean landraces of common bean. Crop Sci. 41:854-862.

Burkholder,W.H. 1918. The production of an anthracnose-resistant white marrow bean. Phytopathology 8:353-359. 
Burkholder, W.H. 1923. The gamma strain of Colletotrichum lindemuthianum (Sacc. et Magn.) B. et C. Phytopathology 13:316-323.

Caixeta, E.T., A. Borém, and J.D. Kelly. 2003. Microsatellite markers for common bean. Annu. Rpt. Bean Improv. Coop. 46:158-159.

Cardenas, F., M.W. Adams, and A. Andersen. 1964. The genetic system for reaction of field beans (Phaseolus vulgaris L.) to infection by three physiologic races of Colletotrichum lindemuthianum. Euphytica 13:178-186.

Castanheira, A.L.M., J.B. dos Santos, D.F. Ferreira, and L.C. Melo. 1999. Identification of common bean alleles resistant to anthracnose using RAPD. Genet. Mol. Biol. 22:565-569.

Creusot, F., C. Macadre, E. Ferrier Cana, C. Riou, V. Geffroy, M. Sevignac, M. Dron, and T. Langin. 1999. Cloning and molecular characterization of three members of the NBS-LRR subfamily located in the vicinity of the $\mathrm{Co}-2$ locus for anthracnose resistance in Phaseolus vulgaris. Genome 42:254-264.

de Arruda, M.C. A.L. Alzate-Marin, J.M. Chagas, M.A. Moreira, and E.G. de Barros. 2000. Identification of random amplified polymorphic DNA markers linked to the $\mathrm{Co}-4$ resistance gene to Colletotrichum lindemuthianum in common bean. Phytopathology 90:758-761.

Dillard, H. R. and A.C. Cobb. 1993. Survival of Colletotrichum lindemuthianum in bean debris in New York State. Plant Dis. 77:1233-1238.

Drijfhout, E. 1978. Genetic interaction between (Phaseolus vulgaris L.) and bean common mosaic virus with implications for strain identification and breeding for resistance. Agric. Res. Rpt. 872, Ctr. Agr. Publ. Doc., Pudoc, Wageningen, The Netherlands.

Drijfhout, E. and J.H.C. Davis. 1989. Selection of a new set of homogeneously reacting bean (Phaseolus vulgaris) differentials to differentiate races of Colletotrichum lindemuthianum. Plant Pathol. 38:391-396.

Duvick, D.N. 1996. Plant breeding, an evolutionary concept. Crop Sci. 36:539-548.

Falconí, E., J. Ochoa, E. Peralta, and D. Danial. 2003. Virulence pattern of Colletotrichum lindemuthianum in common bean in Ecuador. Annu. Rpt. Bean Improv. Coop 46:167-168.

Ferreira, J.J., M.A. Fueyo, A.J. Gonzalez, and R. Giraldez. 1998. Incorporation of genetic resistance to anthracnose in the bean variety "Faba Granja Asturiana" (Phaseolus vulgaris L.), p. 143-144. In: International symposium on breeding of protein and oil crops. Eucarpia Pontevedra, Spain.

Ferreira, J.J., C. Rodriquez, and R. Giraldez. 2000. Identificacion, mediante tests de alellismo, de los genes de resistencia a antracnosis presentes en lineas mejorados de faba granja asturiana, $\mathrm{p}$. 123-128. In: II Seminario de Judia de la Peninsula Iberica. Actas de la Asociacion Espanol de Leguminosas. Vol 1. Villaviciosa, Asturias, Spain.

Ferreira, J.J., C. Rodriguez, A. Pañeda, and R. Giraldez. 2003. Allelism test for resistance to race 38 of anthracnose in common bean differential cultivar, 'Widusa'. Annu. Rpt. Bean Improv. Coop. 46:169-170.

Ferrier-Cana, E., V. Geffroy, C. Macadre, F. Creusot, P. Imbert-Bollore, M. Sevignac, and T. Langin. 2003. Characterization of expressed NBS-LRR resistance gene candidates from common bean. Theor. Appl. Genet. 106:251-261.

Flor, H.H. 1947. Host parasite interaction in flax rust-Its genetics and other implications. Phytopathology 45:680-685.

Fouilloux, G. 1976. Bean anthracnose: New genes of resistance. Annu. Rpt. Bean Improv. Coop. 19:36-37.

Fouilloux, G. 1979. New races of bean anthracnose and consequences on our breeding programs, $\mathrm{p}$. 221-235 In: H. Maraite and J.A. Meyer (eds). Diseases of Tropical Food Crops. Louvain-laNeuve, Belgium.

Freyre, R., P.W. Skroch, V. Geffroy, A.F. AdamBlondon, A. Shirmohamadali, W.C. Johnson, V. Llaca, R.O. Nodari, P.A. Pereira, S.M. Tsai, J. Tohme, M. Dron, J. Nienhuis, C.E. Vallejos, and P. Gepts. 1998. Towards an integrated linkage map of common bean. 4. Development of a core linkage map and alignment of RFLP maps. Theor. Appl. Genet. 97:847-856.

Freytag, G.F., J.D. Kelly, M.W. Adams, J. Lopez Rosa, J. Beaver, and R. Echavez Badel. 1985. Registration of two navy bean breeding lines, L226-10 and L227-1. Crop Sci. 25:714.

Gantet, P., P. Bettini, J. Grisvard, and M. Dron. 1991. Genetic linkage between Mex 2, a specific resistance gene to anthracnose, and Anp, a gene involved in pod anthocyanin accumulation in bean. Plant Dis. 75:941-942.

Geffroy,V.1997. Dissection génétique de la résistance à Colletotrichum lindemuthianum, agent de l'anthracnose, chez deux génotypes représentatifs des pools géniques de Phaseolus vulgaris. $\mathrm{PhD}$ thesis. Inst. Natl. Agron., Paris-Grignon.

Geffroy V., F.J. Creusot, J. Falquet, M. Sevignac, A.F. Adam-Blondon, H. Bannerot, P. Gepts, and M. Dron. 1998. A family of LRR sequences in the vicinity of the $\mathrm{Co}-2$ locus for anthracnose resistance in Phaseolus vulgaris and its potential use in marker-assisted selection. Theor. Appl. Genet. 96:494-502.

Geffroy V., S. Delphine, J.C.F. de Oliveira, M. Sevignac, S. Cohen, P. Gepts, C. Neema, T. Langin, and M. Dron. 1999. Identification of an ancestral resistance gene cluster involved in the coevolution process between Phaseolus vulgaris and its fungal pathogen Colletotrichum lindemuthianum. Mol. Plant-Microbe Interact. 12:774-784.

Geffroy V., M. Sevignac, J.C.F. de Oliveira, G. Fouilloux, P. Skroch, P. Thoquet, P. Gepts, T. Langin, and M. Dron. 2000. Inheritance of partial resistance against Colletotrichum lindemuthianum in Phaseolus vulgaris and co-localization of quantitative trait loci with genes involved in specific resistance. Mol. Plant-Microbe Interact. 13:287-296

Gepts, P. 1988. A Middle American and an Andean common bean gene pool, p. 375-390. In: P. Gepts (ed.). Genetic resources of Phaseolus beans; their maintenance, domestication, and utilization. Kluwer, London.

Gepts, P. 1999. Development of an integrated linkage map, p. 53-91. In: S.P. Singh (ed.). Developments in Plant Breeding. vol. 7. Common bean improvement in the twenty-first century. Kluwer Acad. Publ. Dordrecht, The Netherlands.

Gonçalves-Vidigal, M.C. 1994. Herençia da resistencia as raças alfa, deltae capa de Colletotrichum lindemuthianum (Sacc. et Magn.) Scrib. No feijoeiro (Phaseolus vulgaris L.) PhD thesis. Universidade Federal de Viçosa, Viçosa, Brazil.

Gonçalves-Vidigal, M.C., A.A. Cardoso, C. Vieira, and L.S. Saraiva. 1997. Inheritance of anthracnose resistance in common bean genotypes PI 207262 and $A B$ 136. Brazilian J. Genetics 20:59-62.

Gonçalves-Vidigal, M.C., N.S. Sakiyama, V.R. Oliveira, A.T. Amaral Junior, P.S. Vidigal Filho, and L. Silverio. 1999. Experimental evidence of a single dominant gene (Co- 6 ) controlling $\mathrm{AB} 136$ resistance to races 31 and 69 of Colletotrichum lindemuthianum. Annu. Rep. Bean Improv. Coop. 42:11-12.

Gonçalves-Vidigal, M.C., N.S. Sakiyama, P.S. Vidigal Filho, A.T. Amaral Junior, J.P. Poletine, and V.R. Oliveira. 2001. Resistance of common bean cultivar AB 136 to races 31 and 69 of Colletot- richum lindemuthianum: The Co-6 locus. Crop Breed. Appl. Biotechnol. 1:99-104.

Gonçalves-Vidigal, M.C., V. Vallejo, and J.D. Kelly. 2003. Characterization of the anthracnose resistance in the differential cultivar Widusa. Annu. Rpt. Bean Improv. Coop. 46:175-176.

Gonzalez, M., R. Rodriguez, M.E. Zavala, J.L. Jacobo, F. Hernadez, J. Acosta, O. Martinez, and J. Simpson. 1998. Characterization of Mexican isolates of Colletotrichum lindemuthianum by using differential cultivars and molecular markers. Phytopathology 88:292-299.

Haley, S.D., P.N. Miklas, J.R. Stavely, J. Byrum, and J.D. Kelly. 1993. Identification of RAPD markers linked to a major rust resistance gene block in common bean. Theor. Appl. Genet. 86:505-512.

Hallard, J. and G. Trebuchet. 1976. Bean anthracnose in Western Europe. Annu. Rpt. Bean Improv. Coop. 19:44-46.

Hubbeling, N. 1976. Selection for resistance to anthracnose, particularly in respect to the "ebnet" race of Colletotrichum lindemuthianum. Annu. Rpt. Bean Improv. Coop. 19:49-50.

Hubbeling, N. 1977. The new jota race of Colletotrichum lindemuthianum. Annu. Rpt. Bean Improv. Coop. 20:58.

Kelly, J.D. 2000. Anthracnose races present on both wild and cultivated Phaseolus vulgaris in Mexico. Annu. Rpt. Bean Improv. Coop. 43:184-185.

Kelly, J.D., L. Afanador, and L.S. Cameron. 1994. New races of Colletotrichum lindemuthianum in Michigan and implications in dry bean resistance breeding. Plant Dis. 78:892-894.

Kelly, J.D., L. Afanador, and S.D. Haley. 1995 Pyramiding genes for resistance to bean common mosaic virus. Euphytica 82:207-212.

Kelly, J.D., P. Gepts, P.N. Miklas, and D.P. Coyne. 2003. Tagging and mapping of genes and QTL and molecular marker-assisted selection for traits of economic importance in bean and cowpea. Field Crops Res. 82:135-154.

Kelly, J.D. and P.N. Miklas. 1998. The role of RAPD markers in breeding for disease resistance in common bean. Mol. Breed. 4:1-11.

Kelly, J.D., J.R. Stavely, and P.N. Miklas. 1996. Proposed symbols for rust resistance genes. Annu. Rpt. Bean Improv. Coop. 39:25-31.

Kelly, J.D. and V.A. Vallejo. 2004. QTL analysis of multigenic disease resistance in plant breeding. In: S. Tuzun and E. Bent (eds.). Multigenic and induced systemic resistance in plants (in press).

Kelly, J.D. and R.A. Young. 1996. Proposed symbols for anthracnose resistance genes. Annu. Rpt. Bean Improv. Coop. 39:20-24.

Kruger, J., G.M. Hoffmann, and N. Hubbeling. 1977. The kappa race of Colletotrichum lindemuthianum and sources of resistance to anthracnose in Phaseolus beans. Euphytica 26:23-25.

Lamb, C.J., M.A. Lawton, M. Dron, and R.A. Dixon. 1989. Signals and transduction mechanisms for activation of plant defenses against microbial attack. Cell 56:215-224.

Leakey, C.L.A. and M. Simbwa-Bunnya. 1972. Races of Colletotrichum lindemuthianum and implications for bean breeding in Uganda. Ann. Appl. Biol. 70:25-34.

López, C.E., I.F.Acosta, C. Jara, F. Pedraza, E. GaitanSolis, G. Gallego, S. Beebe, and J. Tohme. 2003. Identifying resistance gene analogs associated with resistance to different pathogens in common bean. Phytopathology 93:88-95.

Mahuku, G.S.,C.E. Jara, C.Cijiao, and S. Beebe. 2002 Sources of resistance to Colletotrichum lindemuth ianum in the secondary gene pool of Phaseolus vulgaris and in crosses of primary and secondary gene pools. Plant Dis. 86:1383-1387.

Mastenbroek, C. 1960. A breeding programme for resistance to anthracnose in dry shell haricot beans. 
based on a new gene. Euphytica 9:177-184.

McClean, P., R. Lee, C. Otto, P. Gepts, and M. Bassett. 2002. Molecular and phenotypic mapping of genes controlling seed coat pattern and color in common bean (Phaseolus vulgaris L.). J. Hered. 93:148-152.

McIntosh, R.A., C.R. Wellings, and R.F. Park. 1995 Wheat rusts, an atlas of resistance genes. Kluwer Acad. Pub. Dordrecht, Boston, London.

McRostie, G.P. 1919. Inheritance of anthracnose resistance as indicated by a cross between a resistant and a susceptible bean. Phytopathology 9:141-148.

Melotto, M., R.S. Balardin, and J.D. Kelly. 2000a. Host-pathogen interaction and variability of Colletotrichum lindemuthianum, p. 346-361. In: D. Prusky, S. Freeman, and M.B. Dickman (eds.). Colletotrichum host specificity, pathology, and host-pathogen interaction. APS Press St. Paul, Minn.

Melotto, M., M.F. Coelho, A. Pedrosa-Harand, J.D. Kelly, and L.E.A. Camargo. 2004. The anthracnose resistance locus $\mathrm{Co}-4$ of common bean is located on chromosome 3 and contains putative disease resistance-related genes. Theor. Appl. Genet. 109:(Online: 10.1007/s00122004-1697-6)

Melotto, M. and J.D. Kelly. 1998. SCAR markers linked to major disease resistance genes in common bean. Annu. Rpt. Bean Improv. Coop. 41:64-65

Melotto, M. and J.D. Kelly. 2000. An allelic series at the $\mathrm{Co}-1$ locus conditioning resistance to anthracnose in common bean of Andean origin. Euphytica 116:143-149.

Melotto, M. and J.D. Kelly. 2001. Fine mapping of the Co-4 locus of common bean reveals a resistance gene candidate, $\mathrm{COK}-4$ that encodes for a protein kinase. Theor. Appl. Genet. 103:508-517.

Melotto, M., V. Vallejo, H. Awale, and J.D. Kelly. 2000b. Use of RAPD and AFLP analysis to tag the Co-1 gene conditioning resistance to bean anthracnose. Annu. Rpt. Bean Improv. Coop. 43:84-85.

Méndez de Vigo, B. 2001. Mapa genético de Phaseolus vulgaris $\mathrm{L}$. y resistencia a antracnosis en faba granja asturiana. $\mathrm{PhD}$ thesis. Univ. Oviedo, Oviedo, Spain.

Mendez de Vigo, B., C. Rodriguez, A. Pañeda, R. Giraldez, and J.J. Ferreira. 2002. Development of a SCAR marker linked to $\mathrm{Co}-9$ in common bean. Annu. Rpt. Bean Improv. Coop. 45:116-117.

Mendoza, A., F. Hernandez, S. Hernandez, D. Ruiz, O. Martinez de la Vega, G. de la Mora, J. Acosta, and J. Simpson. 2001. Identification of Co-1 anthracnose resistance and linked molecular markers in common bean line A193. Plant Dis. $85: 252-255$.

Menezes, J.R. and J.C. Dianese. 1988. Race characterization of Brazilian isolates of Colletotrichum lindemuthianum and detection of resistance to anthracnose in Phaseolus vulgaris. Phytopathology 78:650-655

Meyers, B.C., D.B. Chin, K.A. Shen, S. Sivaramakrishnan, D.O. Lavelle, Z. Zhang, and R.W. Michelmore. 1998. The major resistance gene cluster in lettuce is highly duplicated and spans several megabases. Plant Cell 10:1817-1832

Michelmore, R.W. and B.C. Meyers. 1998. Clusters of resistance genes in plants evolve by divergent selection and a birth-and-death process. Genome Res. 8:1113-1130.

Miklas, P.N., R. Delmore V. Stone, M.J. Daly, J.R. Stavely, J.R. Steadman, M.J. Bassett, and J.S. Beaver. 2000a. Bacterial, fungal, and viral disease resistance loci mapped in a recombinant inbred common bean population ('Dorado'/XAN 176).
J. Amer. Soc. Hort. Sci. 125:476-481.

Miklas, P.N. and J.D. Kelly. 2002. The use of MAS to develop pinto bean germplasm possessing $\mathrm{Co}-4^{2}$ gene for anthracnose resistance. Annu. Rpt. Bean Improv. Coop. 45:68-69.

Miklas, P.N., R.C. Larsen, R. Riley, and J.D. Kelly. 2000b. Potential marker-assisted selection for $b c$ $1^{2}$ resistance to bean common mosaic potyvirus in common bean. Euphytica 116:211-219.

Muhalet, C.S., M.W. Adams, A.W. Saettler, and A. Ghaderi. 1981. Genetic system for the reaction of field beans to beta, gamma, and delta races of Colletotrichum lindemuthianum. J. Amer. Soc. Hort. Sci. 106:601-604.

Pastor-Corrales, M.A. 1991. Estandarización de variedades diferenciales y de designación de razas de Colletotrichum lindemuthianum. Phytopathology 81:694 (abstr.).

Pastor-Corrales, M.A. and J.C.Tu. 1989.Anthracnose, p. 77-104. In: H.F. Schwartz and M.A. PastorCorrales (eds.). Bean production problems in the tropics. CIAT, Cali, Colombia.

Pastor-Corrales, M.A., O.A. Erazo, E.I. Estrada, and S.P. Singh. 1994. Inheritance of anthracnose resistance in common bean accession G 2333. Plant Dis. 78:959-962.

Pastor-Corrales, M.A., M.M. Otoya, A. Molina, and S.P. Singh. 1995. Resistance to Colletotrichum lindemuthianum from Middle America and Andean South America in different common bean races. Plant Dis. 79:63-67.

Pedrosa, A., C.E. Vallejos, A. Bachmair, and D. Schweizer. 2003. Integration of common bean (Phaseolus vulgaris L.) linkage and chromosomal maps. Theor. Appl. Genet. 106:205-212.

Poletine, J.P., M.C. Gonçalves-Vidigal, P.S. Vidigal Filho, C.A. Scapim, and L. Silverio. 1999. Inheritance of anthracnose resistance to Colletotrichum lindemuthianum race 69 in common bean genotype PI 207262. Acta Sci. 21:447-451.

Poletine, J.P., M.C. Gonçalves-Vidigal, P.S. Vidigal Filho, C.A. Scapim, L. Silverio, and C. Thomazella. 2000. Inheritance of resistance to races 69 and 453 of Colletotrichum lindemuthianum in the common bean. Brazilian Arch. Biol. Technol. 43:479-485.

Rodriguez, M.A., H.F. Ramirez, M.C. Valencia, O. Voysest, and J.W. White. 1995. Catalog of advanced bean lines from CIAT. CIAT, Cali, Colombia.

Rodriguez-Guerra, R., M.T. Ramirez-Rueda, O. Martinez de la Vega, and J. Simpson. 2003. Variation in genotype, pathotype and anastomosis groups of Colletotrichum lindemuthianum isolates in Mexico. Plant Pathol. 52:228-235.

Rodríguez-Suárez, C., A. Pañeda, J.J. Ferreira, and R. Giráldez. 2004. Allelic relationships of anthracnose resistance gene cluster B4 in common bean. Annu. Rpt. Bean Improv. Coop. 47:145-146.

Schwartz, H.F., M.A. Pastor-Corrales, and S.P. Singh. 1982. New sources of resistance to anthracnose and angular leaf spot of beans (Phaseolus vulgaris). Euphytica 31:741-754.

Sicard, D., Y. Michalakis, M. Dron, and C. Neema. 1997. Genetic diversity and pathogenic variation of Colletotrichum lindemuthianum in the three centers of diversity of its host, Phaseolus vulgaris. Phytopathology 87:807-813.

Silverio, L., M.C. Vidigal, P.S. Vidigal Filho, M.A.A. Barelli, C. Thomazella, and W.M.C. Nunes. 2002. Genetic resistance to Colletotrichum lindemuthianum race 2047 in G 2333. Annu. Rpt. Bean Improv. Coop. 45:74-75.

Singh, S.P., P. Gepts, and D.G. Debouck. 1991. Races of common bean (Phaseolus vulgaris, Fabaceae). Econ. Bot. 45:379-396.
Stavely, J.R. 1984a. Genetics of resistance to Uromyces phaseoli in a Phaseolus vulgaris line resistant to most races of the pathogen. Phytopathology 74:339-344.

Stavely, J.R. 1984b. Pathogenic specialization in Uromyces phaseoli in the United States and rust resistance in bean. Plant Dis. 68:95-99.

Stavely, J.R. 2000. Pyramiding rust and viral resistance genes using traditional and marker techniques in common bean. Annu. Rpt. Bean Improv. Coop. 43:1-4.

Steadman, J.R., M.A. Pastor-Corrales, and J.S. Beaver. 2002. An overwiew of the $3^{\text {rd }}$ bean rust and $2^{\text {nd }}$ bean common bacterial blight international workshops, 4-8 Mar. 2002, Pietermaritzburg, South Africa. Annu. Rpt. Bean Improv. Coop. 45:120-124.

Tu, J.C. 1992. Colletotrichum lindemuthianum on bean. Population dynamics of the pathogen and breeding for resistance, p. 203-224. In: J.A. Bailey and M.J. Jeger (eds.). Colletotrichum: Biology, pathology and control. CAB Intl., Wallingford, U.K.

Tu, J.C. 1994. Occurrence and characterization of the alpha-Brazil race of bean anthracnose ( $\mathrm{Col}$ letotrichum lindemuthianum) in Ontario. Can. J. Plant Pathol. 16:129-131.

Tu, J.C., J.W. Sheppard, and D.M. Laidlaw. 1984. Occurrence and characterization of the epsilon race of bean anthracnose in Ontario. Plant Dis. 68:69-70.

Vallejo, V.A., H.E. Awale, and J.D. Kelly. 2003. Characterization of the anthracnose resistance in the Andean bean cultivar Jalo EEP558. Annu. Rpt. Bean Improv. Coop. 46:179-180.

Vallejo, V. and J.D. Kelly. 2001. Development of a SCAR marker linked to the Co-5 locus in common bean. Annu. Rpt. Bean Improv. Coop. 44:121-122.

Vallejo, V. and J.D. Kelly. 2002. The use of AFLP analysis to tag the $\mathrm{Co}-\mathrm{I}^{2}$ gene conditioning resistance to bean anthracnose. http:/www. intl-pag.org/pag/10/abstracts/PAGX P233.html Plant and Animal Genome X Conference 2002, San Diego, Calif.

Vear, F., L. Gentzbittel, J. Philippon, S. Mouzzeyar, E. Mestries, P. Roeckel-Dreevet, De. Tourvieille, D. Labrouche, and P. Nicolas. 1997. The genetics of resistance to five races of downy mildew (Plasmopara halstedii) in sunflower (Helianthus annuus). Theor. Appl. Genet. 95:584-589.

Young, R.A. and J.D. Kelly. 1996a. Characterization of the genetic resistance to Colletotrichum lindemuthianum in common bean differential cultivars. Plant Dis. 80:650-654.

Young, R.A. and J.D. Kelly. 1996b. RAPD markers flanking the Are gene for anthracnose resistance in common bean. J. Amer. Soc. Hort. Sci. 121:37-41.

Young, R.A. and J.D. Kelly. 1996c. Is the anthracnose resistance ' $A$ ' gene the same in cultivars belonging to both bean gene pools? Annu Rpt. Bean Improv. Coop. 39:296-297.

Young, R.A. and J.D. Kelly. 1997a. RAPD markers linked to three major anthracnose resistance genes in common bean. Crop Sci. 37:940-946.

Young, R.A. and J.D. Kelly. 1997b. Tests of allelism for the anthracnose resistance $C o-1$ gene. Annu Rpt. Bean Improv. Coop. 40:128-129.

Young, R.A., M. Melotto, R.O. Nodari, and J.D. Kelly. 1998. Marker assisted dissection of oligogenic anthracnose resistance in the common bean cultivar, G2333. Theor. Appl. Genet. 96:87-94.

Zeller, F.J. and S.L.K. Ksam. 1998. Progress in breeding for resistance to powdery mildew in common wheat (Triticumaestivum L.), p. 178. Proc. $9^{\text {th }}$ Intl. Wheat Genet. Symp., Saskatoon. 